\title{
Challenges, Capability and Will: Is NATO Relevant in the Twenty-first Century?
}

\author{
A Monograph \\ by \\ LTC James K. Dunivan \\ United States Army
}

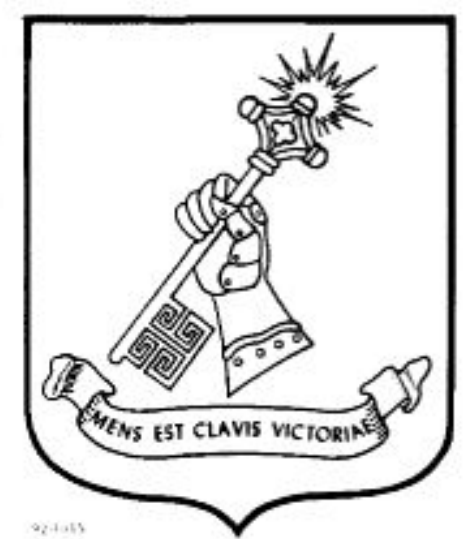

School of Advanced Military Studies

United States Army Command and General Staff College

Fort Leavenworth, Kansas

2015

Approved for public release; distribution is unlimited. 


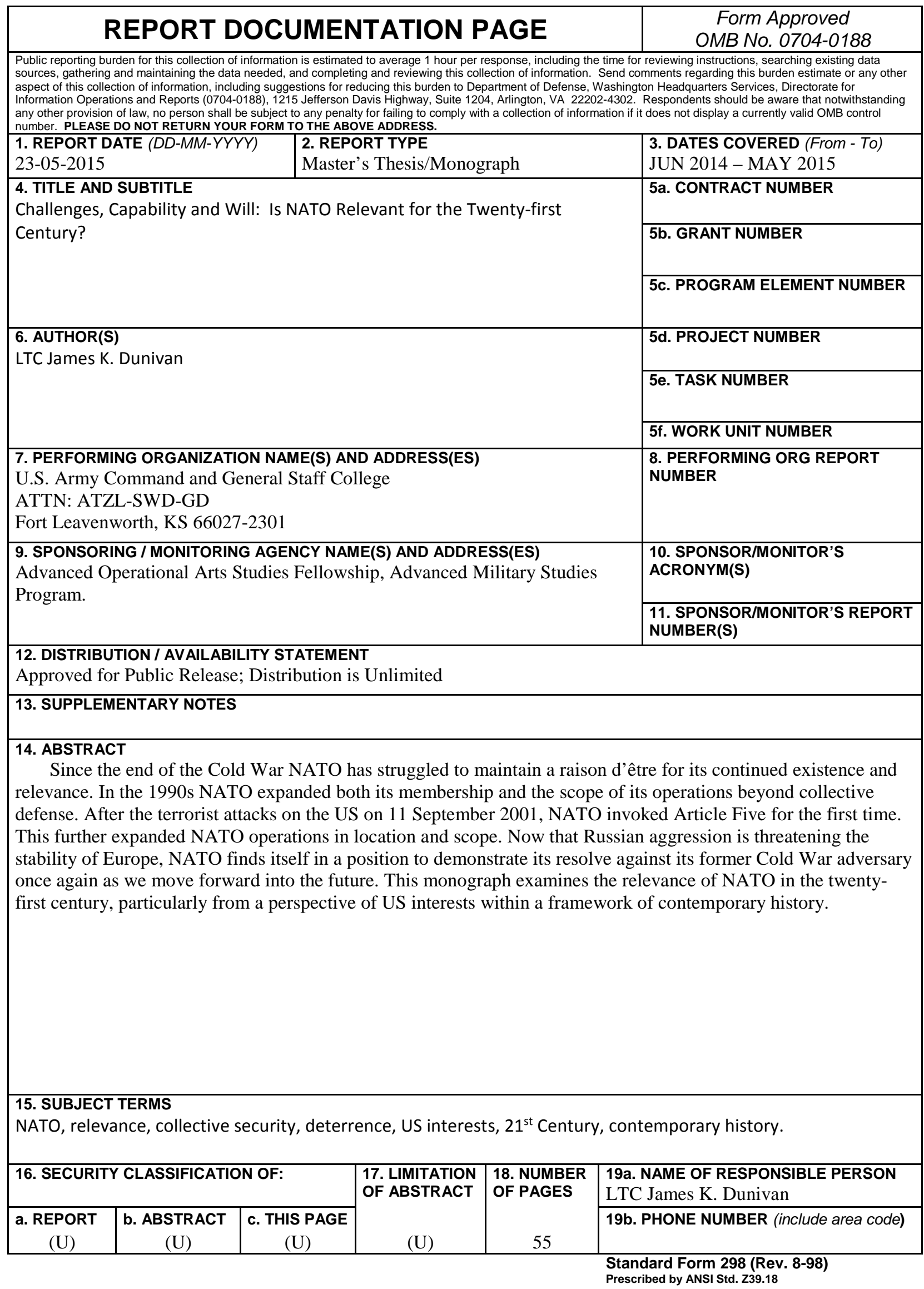




\section{Monograph Approval Page}

Name of Candidate: $\quad$ LTC James K. Dunivan

Monograph Title: Challenges, Capability and Will: Is NATO Relevant in the Twenty-first Century?

Approved by:

Robert T. Davis II, PhD

, Monograph Director

G. Scott Gorman, PhD

, Deputy Director Academics, SAMS

, Director, School of Advanced Military Studies

Henry A. Arnold III, COL, IN

Accepted this $23^{\text {rd }}$ day of May 2015 by:

, Director, Graduate Degree Programs

Robert F. Baumann, PhD

The opinions and conclusions expressed herein are those of the student author, and do not necessarily represent the views of the U.S. Army Command and General Staff College or any other government agency. (References to this study should include the foregoing statement.) 


\begin{abstract}
Challenges, Capability and Will: Is NATO Relevant in the Twenty-first Century? by LTC James K. Dunivan, U.S. Army, 55 pages.

Since the end of the Cold War NATO has struggled to maintain a raison d'être for its continued existence and relevance. In the 1990s NATO expanded both its membership and the scope of its operations beyond collective defense. After the terrorist attacks on the US on 11 September 2001, NATO invoked Article Five for the first time. This further expanded NATO operations in location and scope. Now that Russian aggression is threatening the stability of Europe, NATO finds itself in a position to demonstrate its resolve against its former Cold War adversary once again as we move forward into the future. This monograph examines the relevance of NATO in the twenty-first century, particularly from a perspective of US interests within a framework of contemporary history.
\end{abstract}




\section{Contents}

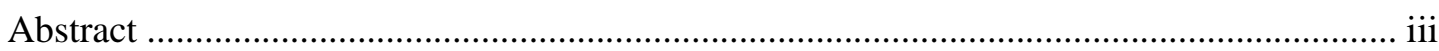

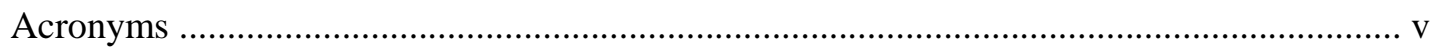

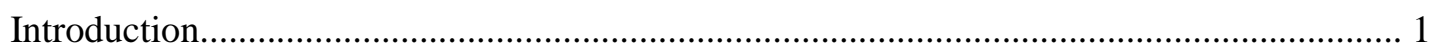

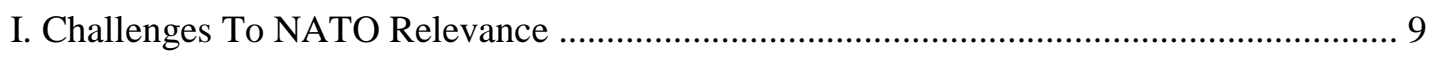

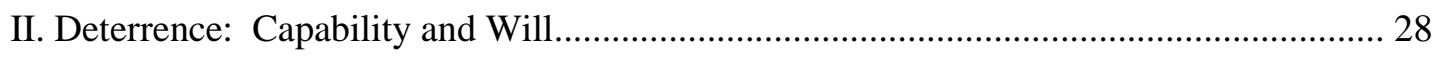

III. Continued Relevance and “A Way” Ahead .................................................................. 38

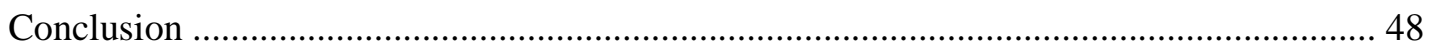

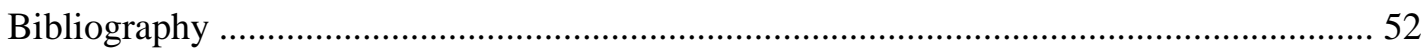




\section{Acronyms}

$\begin{array}{ll}\text { CFI } & \text { Connected Forces Initiative } \\ \text { EU } & \text { European Union } \\ \text { EUCOM } & \text { European Command } \\ \text { GDP } & \text { Gross Domestic Product } \\ \text { ISAF } & \text { International Security Assistance Force } \\ \text { ISIL/ISIS } & \text { Islamic State of Iraq and Levant } \\ \text { JMTC } & \text { Joint Multinational Training Center } \\ \text { NATO } & \text { North Atlantic Treaty Organization } \\ \text { NSC } & \text { National Security Council } \\ \text { QDR } & \text { Quadrennial Defense Review } \\ \text { RAND } & \text { Research and Development } \\ \text { US } & \text { United States }\end{array}$




\section{Introduction}

Europe is home to our most stalwart and capable allies and partners, and the strategic access and support these countries provide is essential to ensuring that the US Armed Forces are more agile, expeditionary, and responsive to global challenges.

--Quadrennial Defense Review 2014

After the conclusion of World War II the United States formally rejected a tradition of political and military “nonentanglement with Europe,” ending a propensity to distance ourselves from European affairs while fully accepting responsibility as a superpower actor upon the world's stage. ${ }^{1}$ What began with ratification of the North Atlantic Treaty and evolved into the North Atlantic Treaty Organization, or NATO, is unparalled among the landmark actions of United States diplomacy. The Alliance differed from previous security arrangements to address a particular cause, with "permissively worded provisions" and "the deliberate omission of a terminal date" to make the treaty open ended and enduring. ${ }^{2}$ Some considered America's first permanent alliance outside the Western Hemisphere, and apparent violation of "George Washington’s Great Rule,” an extension of the Monroe Doctrine “across the Atlantic to buttress Europe's balance of power." ${ }^{3}$ Many hail NATO as "the premier international security institution” and the most successful alliance undertaken in history. ${ }^{4}$ Whether one agrees or not, one cannot easily dismiss the contributions of NATO to European security during the past sixty-plus years.

Perhaps speaking for many who welcome NATO’s commitment to trans-atlantic security, two statements by recent Allied leaders stress the enduring appeal of the Alliance. During his

${ }^{1}$ Lawrence S. Kaplan, The Long Entanglement: NATO’s First Fifty Years (London: Praeger, 1999), 1.

${ }^{2}$ Wallace J. Thies, Why NATO Endures (New York: Cambridge University Press, 2009), 288.

${ }^{3}$ Walter A. McDougall, Promised Land, Crusader State: The American Encounter with the World since 1776 (New York: Houghton Mifflin Company, 1997), 164-165.

${ }^{4}$ Sarwar A. Kashmeri, NATO 2.0: Reboot or Delete? (Washington, DC: Potomac Books, 2011), ix. 
keynote address at the 2011 Munich Security Conference, then NATO Secretary General Anders Fogh Rasmussen outlined his vision of Smart Defense within NATO. Aptly entitled "Building Security in an Age of Austerity” the Secretary General challenged the Alliance to recognize Smart Defense, "how NATO can help nations to build greater security with fewer resources but more coordination and coherence,” as a means to prudently maintain and improve our collective security in a resource constrained environment. ${ }^{5}$ Three years later, at the 2014 Munich Security Conference, then Secretary of Defense Chuck Hagel praised NATO as the "centerpiece of transatlantic security,” then articulated a "renewed and enhanced” partnership and cooperation with

NATO as a fundamental component of the US national security strategy:

In reviewing US defense priorities, tempered by our fiscal realities, it's clear that our military must place an even greater strategic emphasis on working with our allies and partners around the world. . The United States will engage European allies to collaborate more closely, especially in helping build the capabilities of other global partners. We're developing strategies to address global threats as we build more joint capacity, joint capacity with European militaries. In the face of budget constraints here on this continent, as well as in the United States, we must all invest more strategically to protect military capability and readiness. The question is not just how much we spend, but how we spend together. It's not just about burdens we share, but opportunities, as well. ${ }^{6}$

This idea sustains the principles of cooperation the United States has developed for the past twelve years with the International Security Assistance Force (ISAF) in Afghanistan, despite friction caused by different priorities and burden sharing. The remarks also served as a precursor to the 2015 US National Security Strategy premise of a "profound commitment to a Europe that is

${ }^{5}$ Anders F. Rasmussen, NATO Secretary General Keynote Address, 2011 Munich Security Conference, Munich, Germany, February 4, 2011, accessed September 20, 2014, http://www.nato.int/cps/en/natolive/opinions_70400.htm. One can only speculate how much the term Smart Defense reflected the general popularity of Joseph Nye's conceptions of soft power and smart power.

${ }^{6}$ Chuck Hagel, US Secretary of Defense Remarks, 2014 Munich Security Conference, Munich Germany, February 1, 2014, accessed September 20, 2014, http://www.defense.gov/Speeches/Speech.aspx?SpeechID=1828. 
free, whole, and at peace” while bolstering “international capacity to prevent conflict among and within states."7

NATO, continuously acting to implement the policy of Smart Defense, has demonstrated favorable gains in capacity and capability. In any case, the full utility of such an alliance and its associated benefits cannot be measured completely in dollars or Euros. NATO played an essential role in establishing and maintaining security in Europe throughout the Cold War. After the fall of the Soviet Union, however, some believed NATO to be obsolete and expected its dissolution. ${ }^{8}$ To the contrary, NATO has continued to expand its membership through enlargement while committing itself to roles and regions outside the purview of mutual defense in Europe. While conflicts in the Balkans, the ISAF mission in Afghanistan, and Libya have tested the collective will of member states, the Alliance has endured. A voluminous literature, both favorable and negative, has been written about NATO over the past fifteen years. ${ }^{9}$

${ }^{7}$ National Security Strategy 2015, The White House (Washington, DC: February 1, 2015), 10 and 25.

${ }^{8}$ For further reading on the early history and challenges of NATO, along with discussions about continued relevance and existence after the Cold War until the present: McDougall, Promised Land, Crusader State (1996); Kaplan, The Long Entanglement: NATO's First Fifty Years (1999); Victor S. Papacosma, Sean Kay and Mark R. Rubin, NATO after Fifty Years (Wilmington, DE: Scholarly Resources, 2001); Christopher Layne, The Peace of Illusions: American Grand Strategy from 1940 to the Present (Ithaca, NY: Cornell University Press, 2006); Anton Bebler, NATO at 60: The Post-Cold War Enlargement and the Alliance's Future (Amsterdam, NLD: IOS Press, 2010); Gülnur Aybet and Rebecca R. Moore, NATO in Search of a Vision (Washington, DC: Georgetown University Press, 2010); and Stanley R. Sloan, Permanent Alliance?: NATO and the Transatlantic Bargain from Truman to Obama (New York: Continuum, 2010).

${ }^{9}$ Friction and challenges within the Alliance, particularly during conflict and operations, are documented in the following: Richard Holbrooke, To End a War (New York: The Modern Library, 1999); Ivo H. Dalder and Michael O’Hanlon, Winning Ugly: NATO's War to Save Kosovo (Washington, DC: Brookings Institution Press, 2000); Wesley K. Clark, Waging Modern War (New York: Public Affairs, 2001); Lawrence S. Kaplan, NATO Divided, NATO United: The Evolution of an Alliance (Westport, CT: Praeger, 2004); Thies, Why NATO Endures (2009); Kashmeri, NATO 2.0: Reboot or Delete? (2010); and David Auerswald and Stephen Saideman, NATO in Afghanistan: Fighting Together, Fighting Alone (Princeton, NJ: Princeton University Press, 2014). 
Many experienced scholars, diplomats, and pundits seem to make a living by professing the necessity or absurdity of maintaining the Alliance. So why add to this body of work? Because despite the valiant efforts on behalf of the NATO Secretary General and various political and military Allied leaders (to include several US Secretaries of Defense) in advocating the need for military capability and readiness, the harsh reality is that constrained resources and operational fatigue could put NATO funding at risk or deemed unessential by policy decision makers. It is imperative, then, to determine if NATO remains relevant for deterring and resolving conflict as we move forward in establishing our priorities for our national interests and security against emerging threats.

Accordingly, this monograph examines the relevance of NATO for the twenty-first century, particularly from a perspective of US interests within a framework of contemporary history. It is important to identify challenges to the Alliance to mitigate friction and potential points of discord in order to maintain relevance. ${ }^{10} \mathrm{~A}$ discussion of military capability and political will further amplifies the requirements for the Alliance to remain relevant in addressing known and emerging threats to NATO. Finally, having established the challenges, capability and will to demonstrate continued relevance, this paper offers recommendations for four policy adjustments or actions as a way ahead to further solidify NATO's prosperity and ensure continued relevance for the twenty-first century.

${ }^{10}$ Many of the current challenges to the Alliance, along with timely and on-going news and periodicals, are addressed by: Jolyon Howorth and John T.S. Keeler, Defending Europe: The EU, NATO, and the Quest for European Autonomy (New York: Palgrave Macmillan, 2003); Janusz Bugajski and Ilona Teleki, America's New Allies: Central-Eastern Europe and the Transatlantic Link (Washington, DC: Center for Strategic and International Studies, 2006); Roy Allison, Margot Light and Stephen White, Putin's Russia and the Enlarged Europe (London: Chatham House, 2006); and Mahdi D. Nazemroaya, The Globalization of NATO (Atlanta: Clarity Press, 2012); and Joel R. Hillison, Stepping Up: Burden Sharing by NATO’s Newest Members (Carlisle, PA: Strategic Studies Institute, November 2014). 
Relevance can mean many different things, but within the scope of this paper relevance is understood to mean that NATO is achieving its raison d'être as a defensive alliance to "resist aggression, whatever its source.” In the beginning years of the Alliance this served to keep a newly defeated Germany in check while establishing a barricade against Soviet aggression in Europe. ${ }^{11}$ The 1990s brought the collapse of the Soviet Union as well as the proverbial glue that was binding the Alliance together, yet NATO has continued to exist and has prospered. ${ }^{12}$ After the terrorists attacks on the US on 9/11, NATO invoked Article Five for the first time, which further committed NATO to operations in more remote locations and with a vast array of duties as part of a larger coalition. Now that Russian aggression is threatening the stability of Europe, NATO finds itself in a position to demonstrate its resolve against the shadow of its former Cold War adversary once again. To truncate the most quoted quip attributed to British statesman and first NATO Secretary General Lord Hastings Ismay, now, perhaps more than ever, there is a need to "keep the Russians out” and "the Americans in” when it comes to commitment to the security of Europe and the continued relevance of NATO. ${ }^{13}$

Since any examination of relevance demands renewed validation, section one of this paper examines the current challenges to NATO that undermine its utility. Challenges to the Alliance come in many forms, but it is important to focus on those factors that are largely subject to control within NATO. The challenge posed by provision of resources and burden sharing has existed within the Alliance since the Cold War, recurring throughout the ISAF mission and most likely to continue as we move ahead in the current resource constrained environment of the early

${ }^{11}$ Christopher Layne, The Peace of Illusions: American Grand Strategy from 1940 to the Present (Ithaca, NY: Cornell University Press, 2006), 89-90.

${ }^{12}$ Martin Walker, "Variable Geography: America’s Mental Maps of a Greater Europe," International Affairs 76, no. 3 (July 2000), 459-460.

${ }^{13}$ Michael Lind, The American Way of Strategy (New York, NY: Oxford University Press, 2006), 114. 
twenty-first century. Competition for scarce resources contributes to challenges over strategic priorities. The 2010 NATO Strategic Concept, 2014 Wales Summit Declaration and personal writings of accomplished public figures such as Tony Blair, Robert Gates and Richard Holbrooke provide a glimpse into the evolving and sometimes bifurcated "near" or "abroad" strategic priorities of the Alliance. Strategic priorities are exacerbated within the context and in reaction to the various and competing threat streams that pose risks to the security of Europe, the member states and the Alliance as a whole. For all these challenges, since twenty-eight members provide a diverse range of opinions, the Alliance is challenged by further membership enlargement and the difficulty this poses to achieving consensus. While these challenges are over-lapping and affect every member state within the Alliance, they are not insurmountable in terms of keeping NATO relevant for the twenty-first century.

Beyond a valid rationale for stakeholders to maintain NATO, adversaries must view NATO as a capable deterrent in order for the Alliance to be relevant. Deterrence is a combination of capability and political will. NATO's deterrent function is addressed in section two of this paper. In terms of the perception (and reality) of capability, the Allies must demonstrate tactical proficiency, interoperability, combat readiness, and partnership. This is achieved both from a member state perspective and collectively through the NATO concepts of Smart Defense, Connected Forces Initiative and Framework Nations for material and concept development. Remarks by the Secretary General and NATO policy documents highlight all three of these concepts as a means to achieve synergy and complementary capability while avoiding duplication of effort and wasting resources. ${ }^{14}$

${ }^{14}$ Rasmussen Remarks at the Munich Security Conference (2011), Allied Command Transformation Seminar (2012) and Defense Ministers Meeting (2013); NATO Strategic Concepts “The Alliance's Strategic Concept” (1999) and “Active Engagement, Modern Defense” (2010); NATO Headquarters “Building the Alliance’s New Strategic Concept: Allied Command 
In support of NATO policy, the planned reassurance measures proscribed by “The Wales Summit Declaration on the Transatlantic Bond” (2014) demonstrate and highlight this capability and capacity of military force through emphasis on Rapid Response Forces, Regional Alignment Forces and a robust Readiness Action Plan. With all the difficulties that arise in gauging capability, however, the second aspect of deterrence, the demonstration of will, could be the most problematic. Will the Allies invoke Article Five when the time comes, through consensus, regardless of their own individual interests? While there is no way to definitively answer that question, one must assume that Article Five is the backbone of the Alliance and will be honored, but that must be adequately demonstrated to both NATO members and possible enemies in order to achieve deterrence. What can be stated emphatically, however, is the common belief in the necessity and resolve to uphold the Alliance that was vocally expressed in Washington, Brussels and other cities of central-eastern Europe during numerous briefings and interviews in support of this monograph. ${ }^{15}$

Demonstrating that resolve to honor the obligations of the North Atlantic Treaty, through capability and will, is the linchpin to maintaining the relevance of the Alliance. Consequently, the final section of this paper addresses four specific recommendations for reinforcing NATO

Transformation Reflections” (2010); Albright and the Group of Experts' NATO 2020: Assured Security: Dynamic Engagement, Analysis and Recommendations of the Group of Experts on a New Strategic Concept for NATO (2010) and Daalder and the Group of Policy Experts' “Collective Defense and Common Security: Twin Pillars of the Atlantic Alliance” (2014).

${ }^{15}$ Though non-attributional, the opinions and perspectives of various Allied political and military leaders, as well as those of academics and members of think-tanks, were instrumental in gaining both a US and European perspective on the challenges and capabilities of contemporary NATO during various field studies: NATO HQs to include Permanent Representatives and Military Representatives of six member states; EU Military Staff; University of Warsaw Institute for International Affairs; Polish Institute for International Affairs; Poland National Defense University; Baltic Defense College, Tartu, Estonia; the Pentagon; AFRICOM HQ; EUCOM HQ; FORSCOM HQ; Armed Service Committee Staff; Center for New American Security; Center for Strategic and Budgetary Assessments; and the Council on Foreign Relations. 
capability and will, with the ultimate aim of demonstrating the on-going relevance of Alliance. These actions, in conjunction with the agreed aspirational resource contributions agreed during the 2014 NATO Summit in Wales, enable the continued relevance of the Alliance for the twentyfirst century in the face of known challenges and those yet to come.

While the future is unknown, the need for the ability to openly communicate with the leaders of other nations and demonstrate a collective will or position is likely and expected. For many years NATO has adequately provided that table around which the US, member states, partners and others can convene to resolve our differences and maintain trans-atlantic security. The United States, as a key enabler and standard-bearer for the Alliance, must continue to evaluate its commitment to NATO and determine the most efficient and cost effective means to contribute to our national interests and security in Europe and the rest of the global arena. At present, and for the foreseeable years of the twenty-first century, NATO remains a relevant body and worthwhile investment in capability and will that is worthy of its challenges. 


\section{Challenges To NATO Relevance}

Built on a foundation of common interests and shared values, the strength of US alliances and partnerships is unparalleled. People around the world gravitate toward the freedom, equality, rule of law, and democratic governance that American citizens are able to enjoy. From setting global norms to defeating terrorist threats and providing humanitarian assistance, the United States collaborates with allies and partners to accomplish a wide range of strategic, operational, and tactical goals.

--Quadrennial Defense Review 2014

NATO, like many other organizations, has no shortage of challenges. Many of these challenges induce recurrent frictions within the Alliance that threaten both its relevance and its very existence. One challenge mentioned often over the past decade of conflict in Afghanistan has involved resources and burden sharing among members, with some members calling on others to "do more” with less restrictive national caveats. Other challenges come from internal schisms within the organization about strategic priorities and which threats demand the most attention. The challenges that come with NATO’s “Open Door” policy for membership enlargement are other critical obstacles that serve as self-inflicted stress on the structure of the Alliance. Membership expansion has also disrupted relations with Russia. Within all of these challenges lies the ever-present need of consensus among twenty-eight members, which paradoxically serves as one of the greatest challenges while being one of the greatest strengths of the Alliance. Each of these issues must be examined in order to fully appreciate the vulnerabilities, and thereby mitigate risk, to the relevance of NATO.

\section{$\underline{\text { Resources and Burden Sharing }}$}

Since much of the current fiscal environment revolves around budget and resource constraints, it is appropriate to look at NATO burden sharing as a challenge to continued relevance. Regarding the NATO ISAF mission in Afghanistan in particular, former US Secretary of Defense Robert Gates addressed two of his major themes throughout his tenure, which were 
the need for greater European investment in defense and for them to do more in Afghanistan. In his memoir Gates lamented that "Given the economic downturn during this period, telling the Europeans to increase their defense spending was about as useful as shouting down a well.”16 While all NATO members agreed in the 2010 Strategic Concept that "NATO must have sufficient resources - financial, military and human - to carry out its missions, which are essential to the security of Alliance populations and territory,” there is no mechanism to enforce this responsibility of contribution. ${ }^{17}$ There is guidance and agreement for spending, where member states have committed to allocate at least two percent of their gross domestic product (GDP) on defense. Most NATO members do not honor this agreement, however. Typically only five states within the Alliance (one of those consistently being the United States) meet or exceed their resource obligations to the organization. ${ }^{18}$

Those member states not meeting their obligations may be quick to make an argument about the challenges of contributing to both NATO and the European Union (EU). Twenty-one NATO members share responsibilities, to include contribution of resources, to both organizations. While the United States complains about fair and equitable burden sharing and responsibility for security of Europe, there is a perception that Americans are suspect of a strong EU and resist the organization of military capabilities when the Europeans attempt to maintain security and defense on their own. ${ }^{19}$ Since the 1990s, some believe that Washington has deliberately undermined any attempts in Brussels to develop military capabilities outside the umbrella of NATO to prevent the

\section{4), 193-194.}

${ }^{16}$ Robert M. Gates, Duty: Memoirs of a Secretary at War (New York: Alfred A. Knopf,

${ }^{17}$ Strategic Concept for the Defense and Security of the Members of the North Atlantic Treaty Organization. “Active Engagement, Modern Defense.” Adopted by Heads of State and Government at the NATO Summit in Lisbon November 19-20, 2010, 33.

${ }^{18}$ Europe Field Study Notes, September 11, 2014.

${ }^{19}$ Martin L. Cook, The Moral Warrior: Ethics and Service in the US Military (Albany, NY: State University of New York Press, 2004), 17. 
European Union from emerging as “an independent pole of power.” Accordingly, they subscribe to the argument that it is America’s objective “to preserve NATO’s primacy in Euro-Atlanic security affairs, and thus maintain US hegemony on the continent." ${ }^{20}$ Others maintain that the US supports greater European autonomy for defense despite concerns about “decoupling” and interoperability issues. Some Europeans welcome an increased role but have reservations "about both the means and the ends of the enterprise.” ${ }^{21}$ Even those that once thought the EU could replace NATO have come to realize that "Europe is still too weak, too divided and too regional in its security outlook” to replace NATO as the "institution of choice” for crisis management and security. ${ }^{22}$ Valid or not, in any real or perceived struggle for power, people or groups have competing ideas or identities, and will therefore cooperate or compete among themselves to achieve their own respective preferences. ${ }^{23}$

Further explanation is provided by Mancur Olson, who theorized about the logic of rationality and cooperation. “An individual's rational self-interest,” he proposed, "was to shirk on his contributions while continuing to receive benefit from the work of others.” As a consultant with RAND in the 1960s, Olson used this rationale to demonstrate how NATO members had "little or no incentive to provide additional amounts of the collective good,” which led to unequal burden sharing. Despite shared interest in maintaining collective security in Europe, there was no point for a member state to act on that interest if it was going to be achieved regardless of action, input or contribution. ${ }^{24}$ According to Olson, the "apparent tendency for large countries to bear

${ }^{20}$ Layne, 113.

${ }^{21}$ Jolyon Howorth and John T.S. Keeler, eds, Defending Europe: The EU, NATO, and the Quest for European Autonomy (New York: Palgrave Macmillan, 2003), 6.

${ }_{22}$ Anton Bebler, ed., NATO at 60: The Post-Cold War Enlargement and the Alliance's Future (Amsterdam, NLD: IOS Press, 2010), 173.

${ }^{23}$ James G. March, A Primer on Decision Making: How Decisions Happen (New York: The Free Press, 1994), 141.

${ }^{24}$ Quoted in Lawrence Freedman, Strategy: A History (New York: Oxford University 
disproportionate shares of the burdens of multinational organizations, like. . .NATO” is to be expected and accepted as the nature of the Alliance. ${ }^{25}$ While this theory may assist in explaining the unwillingness of most member states to spend two percent or more of their GDP on defense to fulfill obligations to NATO, it falls short in accounting for contributions such as trainers, combat troops, equipment and capabilities offered in support ISAF or other NATO missions. In this effort most member states contributed something, according to their own national will and ability, with the consortium being vital and necessary for the success of Alliance efforts. Joel R. Hillison, in his recent work entitled Stepping Up: Burden Sharing by NATO’s Newest Members, suggested that while Olson's theory of collective action would indicate a propensity for "free riding” among the newest members of NATO, this has not been the case. Members new to the Alliance want to contribute and establish a favorable reputation within NATO, and especially with the United States. New NATO members also seem to view contributions and burden sharing as an appropriate requirement for membership. In examining resource contributions for the Alliance as a whole, Hillison observed "when national interests more closely aligned with Alliance-wide goals, NATO members were more willing to increase their contributions." ${ }^{26}$ With that in mind, it follows that many of the challenges associated with resources and burden sharing can be mitigated by a unified focus on strategic priorities.

\section{$\underline{\text { Strategic Priorities }}$}

As resourcing and burden sharing are a challenge to the relevance of NATO, so too are the efforts of the Alliance within the diverging points of view and interest of the member states regarding level of ambition as to how and where to take action. There is already a natural friction

Press, 2013), 583-584.

${ }^{25}$ Mancur Olson, The Logic of Collective Action: Public Goods and the Theory of Groups (Cambridge, MA: Harvard University Press, 1971), 36.

${ }^{26}$ Joel R. Hillison, Stepping Up: Burden Sharing by NATO’s Newest Members (Carlisle, PA: Strategic Studies Institute, November 2014), 4-6. 
that comes from the competition of resources and priorities in terms of fulfilling the necessary requirements in support of planned Alliance operations and missions with the anticipated and over the horizon requirements of maintaining forces and capabilities to face future security challenges. One also has to consider the inherent conflict within any operational mission such as ISAF where different nations could maintain an alternate tactical focus with associated caveats. Former Secretary of Defense Robert Gates highlighted one such example when he described an engagement with NATO allies to stress the importance of a spring offensive in Afghanistan in being an "alliance offensive.” Other defense ministers were inclined to recommend that a more "balanced, comprehensive approach" was needed and that the alliance "should be focusing more on economic and reconstruction efforts than on boosting force levels.” The Europeans, in his opinion, wanted to focus more on “a very broad long-term mission” similar to nation building while the US administration wanted more narrow, timely, and achievable objectives to enable mission completion. Regardless of which approach was more realistic for the circumstances, "no one ever focused explicitly on this divergence of views between the United States and our NATO allies either in our meetings or publicly,” said Gates, "but it was an important underlying source of friction and frustration.” ${ }^{27}$ While this lack of coordination and convergence of policy may not be directly responsible for any ISAF shortcomings in Afghanistan, it does reinforce the observation that "war may be risky, but fighting as a coalition or as an alliance is harder still."28

All of this friction and frustration is exacerbated as the Alliance struggles to develop its strategic priorities beyond ISAF, be they a return to the original focus on Article Five and collective defense or an acceptance of a more globalized mission set. Despite emphasis on the primacy of collective defense by the group of experts advising upon its content, the final version

${ }^{27}$ Gates, 203.

${ }^{28}$ David Auerswald and Stephen Saideman, NATO in Afghanistan: Fighting Together, Fighting Alone (Princeton, NJ: Princeton University Press, 2014), 2. 
of the NATO Strategic Concept of 2010 acknowledged the need for collective defense but stresses “cooperative security” as a more relevant imperative. Since "the Alliance is affected by, and can affect, political and security developments beyond its borders. . The Alliance will engage actively to enhance international security, through partnership with relevant countries and other international organizations.” ${ }^{29}$ In other words, the real or perceived perception that there are global implications to trans-atlantic security have pushed NATO to accept missions outside the Alliance’s formal geographic region.

This development is not new for NATO. In the 1990s the Alliance initiated its inaugural military missions outside the confines of NATO member territory when it became involved in Bosnia and Kosovo. While a NATO force remains in Kosovo even today, these missions were successful in restoring regional security within Europe and emboldened NATO to acknowledge that it could exceed its historical collective defense posture and "become a force for offensive military interventions beyond its members' borders.” ${ }^{30}$ Consequently, NATO formally ratified this expanded role for out of area missions in 1999 as part of its strategic concept, acknowledging the need for NATO's ability to “account for the global context” under the auspices of crisis management and conflict prevention "in the interest of wider stability." 31

Some perceived this shift in ambition, after the collapse of the Soviet Union and the end of the Cold War, as a "new NATO. . .actively pursuing combat missions and international policing duties. . .to impose. . the maintenance of international law and stability.”32 Richard

${ }^{29}$ NATO Strategic Concept 2010, 8.

${ }^{30}$ Kashmeri, 11.

${ }^{31}$ Strategic Concept for the Defense and Security of the Members of the North Atlantic Treaty Organization. “The Alliance's Strategic Concept.” Adopted by Heads of State and Government at the meeting of North Atlantic Council in Washington, DC April 24, 1999, para. 3, 24 and 29. Language to maintain this out of area role remains in the 2010 Strategic Concept.

${ }^{32}$ Mahdi Darius Nazemroaya, The Globalization of NATO (Atlanta, GA: Clarity Press, 2012), 19. 
Holbrooke, writing about his experience with NATO in the Balkans, prophetically anticipated a more global role for NATO when he wrote about how history teaches us that the world is unpredictable:

There will be other Bosnias in our lives, different in every detail but similar in one overriding manner: they will originate in distant and ill-understood places, explode with little warning, and present the rest of the world with difficult choices - choices between risky involvement and potentially costly neglect. . . The world's richest nation, one that presumes to great moral authority, cannot simply make worthy appeals to conscience and call on others to carry the burden. The world will look to Washington for more than rhetoric the next time we face a challenge to peace. ${ }^{33}$

From this perspective, the United States, along with NATO, should accept a predominate role in maintaining international law and global stability. Within this role, despite any domestic or foreign desire to the contrary, the United States continues to lead the Alliance due to an unwillingness of Europe to maintain a viable defense system or to manage out of area crises without dependence on US capability. ${ }^{34}$

Ironically, it would be an attack on the United States, the "senior partner" in NATO, which would establish the trajectory for NATO’s involvement in its largest undertaking outside of Europe. The terrorist attacks on American soil on September 11, 2001 sent shock waves around the world, with ripple effects felt throughout NATO as the Alliance rallied to invoke Article Five of the North Atlantic Treaty for the first time in its history. The nation attacked was not a "vulnerable European ally, but the superpower itself." 35 Donald Rumsfeld, the Secretary of Defense at the time, likely voiced the sentiments of many people: "Despite my many years of association with the alliance, it had never crossed my mind that NATO might someday step up to

${ }^{33}$ Richard Holbrooke, To End a War (New York: The Modern Library, 1999), 372.

${ }^{34}$ Lawrence S. Kaplan, NATO Divided, NATO United: The Evolution of an Alliance (Westport, CT; Praeger, 2004), 130-131.

${ }^{35}$ Kaplan, NATO Divided, NATO United: The Evolution of an Alliance, 134-135. 
help defend the United States.”36 The immediate response of NATO in coming to the aid of the US, supportive and strong in expressing the condolences of the population of the member states, was to strike back against Al-Qaeda, the Taliban and their threat to NATO as an international problem of the gravest kind. ${ }^{37}$ The analysis as to what type of missions this would involve and where the fight against terrorism would occur was less important at the time, as it was necessary for the US to respond against the threat through rhetoric escalating into ambitious action.

\section{Threat}

The level of ambition should be determined by an appropriate dialectic between the agreed threats to Alliance security and the political will to provide resources to meet those threats. ${ }^{38}$ As with the challenges to resource burden sharing within the Alliance, it is equally difficult to find fully “agreed” threats among the member states. Various threat streams weigh more heavily on some members than others. For example, the eastern European members, many of which were included in the former Warsaw Pact, have a tremendous concern with the ongoing aggression demonstrated by Russia. Other members in southern Europe are more preoccupied with the rise of the Islamic State in Iraq and Syria, as well as radical Islamic fundamentalists that can traverse through open European borders and potentially exercise terrorist activity. Finally, there is the threat to international commerce and the global commons, to include cyberspace, which not only challenges the attention of NATO but also its relevance through action or inaction against this unique threat.

\footnotetext{
${ }^{36}$ Donald Rumsfeld, Known and Unknown (New York: Sentinel, 2011), 350.

${ }^{37}$ Kaplan, NATO Divided, NATO United: The Evolution of an Alliance, 134-135.

${ }^{38}$ NATO Headquarters, Allied Command Transformation, "Building the Alliance's New Strategic Concept: Allied Command Transformation Reflections,” Norfolk, VA: February 2010, 11.
} 
While the collapse of the Soviet Union might have caused many to predict the demise of NATO, the events of the past year in the Ukraine have renewed old fears of Russia as a threat to European security. Some within the halls of NATO headquarters in Brussels have acknowledged that the actions of Vladimir Putin have given the Alliance a renewed purpose. ${ }^{39}$ In a summit declaration in Wales in September 2014, NATO leaders announced that “Russia's aggressive actions against Ukraine have fundamentally challenged our vision of a Europe whole, free, and at peace." ${ }^{40}$ With that renewed sense of purpose in recognizing this aggression, however, a feeling of doubt and insecurity has crept into the mindset of some personnel of member states. This is especially true of those in central and eastern Europe. After decades of living under the yoke of communism, our newest allies in central and eastern Europe sought membership in major international institutions such as NATO to enjoy the collective benefits of the Alliance, including security. The NATO Baltic members and Poland in particular have a perception of instability along their borders and a sense of a growing existential threat from Russia. ${ }^{41}$

To other Allies in Southern Europe though, such as Spain and Italy, the threat of Russian aggression is of less significance than the complex issues associated with illegal migration, refugee and foreign fighter flow, smuggling, and a host of other illicit enterprises across the Mediterranean Sea from Africa and the Levant. ${ }^{42}$ Some in NATO refer to an "Arc of Instability" that begins in Libya and extends through Syria into Iraq. ${ }^{43}$ From a US perspective, a significant

${ }^{39}$ Europe Field Study Notes, September 11, 2014.

${ }^{40}$ The Wales Declaration on the Transatlantic Bond. Heads of State and Government participating in the meeting of the North Atlantic Council in Wales, September 5, 2014, para. 120.

${ }^{41}$ Janusz Bugajski and Ilona Teleki, America's New Allies: Central-Eastern Europe and the Transatlantic Link (Washington, DC: Center for Strategic and International Studies, 2006), 1.

42 John R. Deni, “NATO’s New Trajectories after the Wales Summit,” Parameters 44, no. 3 (Autumn 2014), 57.

${ }^{43}$ Europe Field Study Notes, September 11, 2014. One could easily continue this 'Arc of Instability' reference into Georgia, where it continues to be mired in "frozen conflict” with Russia 
aspect of the "Arc” is development of the Islamic State of Iraq and Levant (ISIL, also identified as ISIS), which poses a significant threat to America, our allies, and the overall stability of the Middle East. To the United States and most of our NATO Allies, ISIL is a terrorist organization that must be addressed within a regional context to contain the threat to our respective interests. ${ }^{44}$ For one NATO member in particular, Turkey, ISIL is a threat in its own backyard. Due to its own domestic considerations with the Kurds, problems with refugees from Syria, and a hostage situation involving several of its diplomats, Turkey must obviously balance its own national interests with the desires of the US and NATO for direct action in addressing ISIL and the associated threat streams along its boundary and the “Arc of Instability” bordering Southern Europe. ${ }^{45}$

Beyond the “Arc of Instability” and the contemporary "Eastern Front” with Russia are other, less geographically defined threats to the Alliance via the global commons of cyberspace. While there is no recognized difference of opinion against cyber warfare in terms of its nature as a threat to the Alliance as a whole, this particular threat challenges the relevance of NATO due to the lack of a definitive response mechanism to a cyber-attack. This fact was made all too clear to Estonia, who had joined NATO to ensure its freedom and security, only to find that "a three-week wave of cyber-attacks” during April 2007 did not constitute aggression upon a member in accordance with Article Five of the North Atlantic Treaty. Regardless of the point that Estonia's government, media and economic institutions had been "knocked off line” and devastated, NATO did not define cyber-attacks as a clear military action requiring an Alliance response. ${ }^{46}$

similar to the Ukraine, but that would further complicate the threat stream that resonates most strongly in Southern Europe.

${ }^{44}$ Ross Harrison, “Towards a Regional Strategy Contra ISIS,” Parameters 44, no. 3 (Autumn 2014), 37.

${ }^{45}$ Harrison, 41.

${ }^{46}$ Kashmeri, 49-51. 
Building upon this experience, the NATO Strategic Concept in 2010 established that cyber-attacks "can reach a threshold that threatens national and Euro-Atlantic prosperity, security and stability” and made it a priority to "develop further our ability to prevent, detect, defend against and recover from cyberattacks." ${ }^{47}$ During the NATO Summit in Wales during September 2014, NATO continued to advance the narrative that "individual allies are responsible for developing the relevant capabilities for the protection of national networks” but also agreed that cyber defense falls under the umbrella of our core collective defense tasks. However, even though a member may wish to petition for an Allied response in the name of collective defense, “a decision as to when a cyber-attack would lead to the invocation of Article Five would be taken by the North Atlantic Council on a case-by-case basis." ${ }^{48}$ It is unlikely that this declaration, given the lack of solid threat attribution and moderate advancement in countermeasures, would prevent another cyber attack similar to the one experienced by Estonia in 2007. Debilitating cyber-attacks will continue to challenge the relevance of the Alliance despite an increasingly unified acceptance of the threat among nations.

General George Casey, reflecting on his time as Multi-National Force Commander in Iraq, wrote that "creating unity of effort among diverse entities beyond your control is, and will continue to be, one of the key tasks that will require the attention of senior leaders in $21^{\text {st }}$-century warfare." ${ }^{49}$ Finding unity of effort in addressing the various threat streams to NATO will not be an easy task, as threat uniquely encompasses the universal stimulus where all member states act within the "common practice of mankind" in accordance with the motives of "fear, honor and

\footnotetext{
${ }^{47}$ NATO Strategic Concept 2010, 11 and 16.

${ }^{48}$ Deni, 60.

${ }^{49}$ George Casey, Strategic Reflections (Washington, DC: National Defense University, 2012), 159.
} 
interest." ${ }^{50}$ Regardless, some type of consensus on prioritization of threat will be required to mitigate challenges to relevance.

\section{Membership Enlargement}

Another great challenge to the relevance of NATO that requires unity of effort for resolution is the enlargement of Alliance membership. NATO’s “Open Door” policy of membership enlargement uniquely serves to both instigate reprisal from the Russians while fracturing the spirit of consensus within the Alliance. Contrary to expectations of dissolution at the end of the Cold War, NATO partners not only maintained the Alliance, but also moved toward enlargement as part of "a broad and long-term strategy supporting the evolution of a peaceful, undivided, and democratic Europe expanding the zone of stability and security eastward." ${ }^{51}$ For the United States, under the leadership of President Bill Clinton on a visit to Europe in 1994, NATO enlargement was never a matter of “if," but "when.”52 For President Clinton it was an opportunity of monumental significance, where "For the first time in history we have the chance to expand the reach of democracy and economic progress across the whole of Europe and to the far reaches of the world." 53

Ironically, the enlargement of NATO membership is one of the few aspects of foreign policy that US Presidential administrations, both Democrat and Republican, have appeared to agree upon since the Clinton administration. ${ }^{54}$ Despite the reservations of figures such as George Kennan, some of our countries most experienced diplomats such as the late Richard Holbrooke and former Secretary of State Madeleine Albright have supported NATO enlargement. It is worth

${ }^{50}$ Robert B. Strassler, ed., The Landmark Thucydides: A Comprehensive Guide to the Peloponnesian War (New York: Free Press, 1996), 43.

${ }^{51}$ Janusz Bugajski, et al., Toward an Understanding of Russia: New European Perspectives (New York, NY: Council on Foreign Relations, 2002), 154.

52 Ibid.

${ }^{53}$ McDougall, 201-202.

${ }^{54}$ Layne, 105-106. 
noting, however, that Holbrooke had some reservations in terms of balancing expansion with encroachment and efficiency. Warning against the possibility of unintended outcomes from enlargement, Holbrooke recommended prudence and caution: "NATO, long the private preserve of the nations on one side of the Iron Curtain, could gradually open its doors to qualified Central European nations. It was essential that this be done in a manner that neither threatened Russia nor weakened the alliance.”55

Accordingly, at a ceremony in Paris for the signing of the NATO-Russia Founding Act, President Bill Clinton stood with Russian President Boris Yeltsin and announced that "a great nation and history’s most successful alliance” would now cooperate for the good of all where a “new Russia” and “new NATO” would work together in a “new Europe of unlimited possibility." 56 The Founding Act was pursued by NATO to prevent the Russian government from hindering the enlargement process and to reassure the Russians of continued cooperation despite NATO enlargement. Many in the Alliance thought that Russia's agreement to the Founding Act signaled its acceptance and approval of NATO expansion, but this was not the interpretation of the Russian government nor was it the public opinion of the Russian people. Since NATO enlargement would take the periphery of the Alliance to the borders of Russia, enlargement “appeared to imply a direct threat to an area which the Russian government considered to be within its legitimate sphere of influence." ${ }^{57}$

Russian President Vladimir Putin, speaking at the Munich Security Conference in 2007, voiced his concerns about NATO enlargement and its threat to Russia. Referring to NATO

${ }^{55}$ Holbrooke, 368.

${ }^{56}$ Bill Clinton, "Remarks at a Signing Ceremony for the NATO-Russia Founding Act in Paris, France,” Weekly Compilation of Presidential Documents 33, i. 22 (June 2, 1997), 780-782.

${ }^{57}$ Roy Allison, et al., Putin's Russia and the Enlarged Europe (London: Chatham House, 2006), 4-5. In this regard Russia clung to a concept that most in the West found anachronistic and a reminder of Cold War attitudes. 
expansion as "serious provocation that reduces the level of mutual trust," Putin questioned the motives of Alliance enlargement and considered NATO expansion to be a new form of "Berlin Wall” that would dangerously divide Europe once again. He also reminded the ambassadors in the audience that it was Russia that made the historic decision to remove the Berlin Wall as a show of good faith and cooperation, but the West has consistently failed to maintain our guarantees and agreements. ${ }^{58}$ Rather than guarantees against aggression, NATO actions and strategic communications continue to signal otherwise, despite the best intentions of the Alliance. The bottom line, as a challenge to the relevance of NATO in terms of the Russian perspective, is that NATO enlargement is considered a threat to the security of Russia. ${ }^{59}$

We do not have to agree with this Russian perspective, in fact there are those within the Alliance who tend to view the whole affair as a "classic case of action and reaction as the conflict over motives and intentions” continues to escalate. Tony Blair, the former Prime Minister of Great Britain, tried reasoning with Vladimir Putin that NATO’s expansion and support for democracy should not be viewed as a "strategic bulwark, enfeebling or encircling Russia” but rather as an extension of freedom. ${ }^{60}$ As one scholar has written, “American statements that Russian concerns were 'ludicrous' was true at one level. . .but failed to engage with deeper Russian concerns about long-term security. The United States' failure to understand the perspective of others is one of the country's greatest failings in the post-Cold War era." ${ }^{61}$ More specifically, the perspective of Russia was blatantly unheeded during the agreement and announcement of the NATO Strategic Concept in 2010:

\footnotetext{
${ }^{58}$ Vladimir Putin, Address to the Munich Security Conference, February 10, 2007.

${ }^{59}$ Bugajski, 161.

${ }^{60}$ Tony Blair, A Journey: My Political Life (New York, NY: Alfred A. Knopf, 2010),

${ }^{61}$ Richard Sakwa, “’New Cold War’ or Twenty Years’ Crisis? Russia and International Politics,” International Affairs 84, no. 2 (2008), 256.
} 245. 
NATO's enlargement has contributed substantially to the security of Allies; the prospect of further enlargement and the spirit of cooperative security have advanced stability in Europe more broadly. Our goal of a Europe whole and free, and sharing common values, would be best served by the eventual integration of all European countries that so desire into Euro-Atlantic structures. The door to NATO membership remains fully open to all European democracies which share the values of our Alliance, which are willing and able to assume the responsibilities and obligations of membership, and whose inclusion can contribute to common security and stability. ${ }^{62}$

In view of the renewed affirmation of Alliance in 2010 to continue an “Open Door” policy to membership in NATO, it is no surprise that Russian military doctrine in 2010 maintained NATO enlargement "high on the list of military threats" to reinforce Moscow's long-held perception of the Alliance as a "security threat and challenge to its regional interest."”3

As a result of this Russian assessment and ongoing Russian aggression along its periphery, despite the rhetoric of the "Open Door" to NATO, there is currently no consensus to bring new members into the Alliance. Some members, equating enlargement to increased security, openly believe that "we as an Alliance did not demonstrate courage [at the NATO Summit in Wales in September 2014] to invite four aspirant countries into NATO.” Other Permanent Representatives to NATO expressed that NATO enlargement and membership was "taken off the table for Wales because it was too divisive." ${ }^{64}$ One could argue that this divisive "rift” has existed since the 2008 Bucharest Summit where several member states refused to support the United States’ bid to invite Georgia and the Ukraine into NATO’s Membership Action Plan “due largely to concerns about antagonizing a Russia on which Europe has become increasingly energy dependent." ${ }^{65}$ Regardless of the philosophy one subscribes to in terms of

${ }^{62}$ NATO Strategic Concept 2010, 25-26.

${ }^{63}$ Bettina Renz, "Russian Military Capabilities after 20 Years of Reform," Survival 56, no. 3 (June-July 2014), 72.

${ }^{64}$ Europe Field Study Notes, September 11, 2014.

${ }^{65}$ Gülnur Aybet and Rebecca R. Moore, eds., NATO in Search of a Vision (Washington, DC: Georgetown University Press, 2010), 5. 
NATO enlargement, it is clearly a challenge to the continued relevance of the Alliance if consensus continues to evade resolution to the satisfaction of current and aspiring members to NATO.

\section{$\underline{\text { Consensus }}$}

That being said, consensus in and of itself is one of the primary challenges to the continued relevance of the Alliance. Consensus within NATO constitutes compromise among the membership for action. While the idea of consensus has always served as a fundamental and valued principle within the Alliance, it is worth noting that compromise, by its very definition of agreement through concessions or adjustment, is rarely an optimum solution. ${ }^{66}$ Additionally, in their report to the Secretary General to inform the development of the 2010 NATO Strategic Concept, the Group of Experts put forth that:

there is an inherent tension between a multimember organization that works by consensus and a military/political Alliance operating in a fluid and fast-paced security environment. . .However, the need to achieve agreement. . .can prove arduous, sometimes leading to delays that serve no constructive purpose. In addition, the Alliance needs to prepare for situations where rapid (indeed almost instantaneous) decision-making may be required. ${ }^{67}$

While the Group of Experts was correct to identify this challenge, there has been little to no apparent progress in streamlining the overall process of collaborative decision making for the Alliance. One member of the European Union Military Staff, another organization that has membership size and consensus issues, commented that it is hard to create a shared vision when you have twenty-eight members sitting around the table. ${ }^{68}$ This combination of real or perceived

${ }^{66}$ John P. Kotter, Power and Influence (New York, NY: The Free Press, 1985), 19.

${ }^{67}$ Madeleine Albright, et al., NATO 2020: Assured Security: Dynamic Engagement, Analysis and Recommendations of the Group of Experts on a New Strategic Concept for NATO (Brussels, Belgium: NATO Public Policy Division, May 17, 2010), 34.

${ }^{68}$ Europe Field Study Notes, September 10, 2014. 
less than optimal solutions derived from a cumbersome and obstacle-laden process presents challenges to the reliability and credibility of NATO as a relevant force of action.

While then US Secretary of Defense Donald Rumsfeld was criticized by the media for insulting our partners abroad, he demonstrated an understanding of these conditions detrimental to decision-making and consensus when he chose to inform the North Atlantic Council that "it was not necessary” for the Allies to help the United States and to go into Afghanistan as an Allied force. Many pundits argued that this action revealed our true belief that the Alliance was dysfunctional and "more of a hindrance than a help," which "sent a clear public message that America no longer considered NATO to be its premier platform for fighting today's wars.” ${ }^{69}$ In truth, this was a realistic reaction given Secretary Rumsfeld's personal knowledge and experience of NATO that he gained while serving as the US Ambassador to NATO in the early 1970s under President Nixon. In his memoir, Rumsfeld confessed that "as much as he appreciated the symbolic importance of NATO, Nixon found the alliance frustrating. It operated by consensusrequiring unanimity in any major decision—and Nixon didn’t have a great deal of patience for policy making by committee.” Nor did Rumsfeld for that matter, realizing that consensus was difficult to achieve in any organization, and most especially among a group of respected diplomats operating on instructions from their capitals to maintain their own national interests to the best of their ability. ${ }^{70}$

This belief was validated during the Kosovo campaign in 1999 during an infamous exchange between the Supreme Allied Commander, General Wesley Clark and British Lieutenant General Sir Michael Jackson, then commander of NATO forces in Kosovo. Clark portrayed the event as “a striking example of what was to become an increasingly open "secret” of NATO

\footnotetext{
${ }^{69}$ Kashmeri, 8-9.

${ }^{70}$ Rumsfeld, 147.
} 
operations: NATO commands were like puppets, with two or six or sometimes dozens of strings being pulled from behind the scenes by the nations themselves, regardless of the formalistic commitment of forces.”71 General Clark’s comment provides a first-hand account of coalition truth, whereby regardless of being joined together on a team such as NATO, considerable internal conflict will exist. Groups, people and states have their own ideas and identities, and since not everyone can have everything desired there is a struggle from within to satisfy respective preferences. ${ }^{72}$ General Clark expands upon this phenomenon after seeing it in practice:

And in the case of allied action, the United States will have to recognize that its own national interests will seldom be the same in nature, intensity, scope, or duration as those of its allies and partners. This is the unchangeable truth about groupings of states: they have differing interests. These may derive from different degrees of exposure to the damages of war, varying economic interests in the affected region, historical or cultural relationships with adversaries, or even different national election procedures or timing. Sustaining a common interest sufficient to support military power and its use is therefore a matter of high statesmanship. ${ }^{73}$

Many of the current national representatives to NATO understand the necessity of statesmanship and practice it daily within "the machine room of NATO consensus" at the North Atlantic Council. Most view consensus as a strength of the Alliance, and not a weakness, despite the fact that "it is not perfect or fast.” As one representative stated, “you can make a quick decision on your own and have legitimacy issues, or you can be deliberate and go through the NATO process to have commitment and staying power from consensus." 74 The bottom line is that "NATO is a voluntary association of sovereign nation states. It can be or do no more than all its members want it to be or do. This is both NATO's greatest strength and its greatest potential weakness.”75

${ }^{71}$ Wesley K. Clark, Waging Modern War: Bosnia, Kosovo, and the Future of Combat (New York, NY: Public Affairs, 2002), 399.

${ }^{72}$ March, 104 and 141.

${ }^{73}$ Clark, 13.

${ }^{74}$ Europe Field Study Notes, September 11, 2014.

${ }^{75}$ Victor S. Papacosma, Sean Kay, and Mark R. Rubin, eds., NATO after Fifty Years (Wilmington, DE: Scholarly Resources, 2001), 21. 
Within this section we have examined several challenges to NATO which are sources of friction that threaten the relevance of the Alliance. From burden sharing and caveats to strategic priorities of collective defense or out of area operations, to threat streams to the east or to the south, to internal "threats" such as consensus with the Alliance and agreement as to whether or not to continue enlargement with new members, there is no shortage of challenges to the relevance of NATO in the Twenty-first century. Efforts at examination and analysis of these challenges have been put forth in order to allow a better appreciation of the vulnerabilities and to the relevance of NATO. Let us now turn to the capabilities of NATO and possible courses of action to mitigate the risk of these challenges to maintaining this most effective Alliance. 


\section{Deterence: Capability and Will}

We have deep and abiding interests in a European partner that is militarily capable and politically willing to join with the United States to address future security challenges. Our commitment to the NATO Alliance is steadfast and resolute, and the United States will work with allies and partners to ensure NATO remains a modern and capable alliance.

--Quadrennial Defense Review 2014

At the conclusion of World War II the United States formally rejected a tradition of political and military "nonentanglement with Europe.” This came in the wake of two major wars and with the potential for conflict with the Soviet Union. From an American perspective this made sense, as peace in Europe and the containment of communism were in the best interest of the United States, and the identity and interests of the formulator provides most of the meaning and context of strategy. Since that time and up to the present day, many still believe that the United States has few, if any, interests greater or more vital than the security and defense of Europe. ${ }^{76}$ Having already acknowledged that NATO has been a significant contributor to the success of that policy up to the present, one of the problems with continued success over the long term is that it has created a sense of complacency. Complacency can manifest itself in many ways, but the most relevant context to NATO's ability to maintain a posture of deterrence lies within its members' ability to demonstrate military power and a willingness to project or utilize it.

\section{Capability}

One of the most critical constraints on demonstrating military power within NATO is the initiative of member states to spend enough and wisely on defense to maintain the required capabilities. ${ }^{77}$ The challenges to NATO’s relevance brought forth by friction due to a perception of unequal burden sharing continues to be an issue. Most members agree that defense spending

\footnotetext{
${ }^{76}$ Builder, 53 and 139.

${ }^{77}$ Menon, 86.
} 
goals are "aspirational,” and while only five members of the Alliance routinely achieve the allocation of two percent or greater of their Gross Domestic Product for defense, it is more important to emphasize usable military capabilities rather than a spending percentage. ${ }^{78}$ The importance of military capabilities has long been recognized by the United States, along with the belief that "the capabilities of our allies are. . .a function of our own" in maintaining collective security ${ }^{79}$ As the authors of "United States Objectives and Programs for National Security,” or National Security Council Paper NSC-68, wrote in 1950, "the role of military power is to serve the national purpose by deterring an attack upon us while we seek by other means to create an environment in which our free society can flourish.” 80

Written to support the US policy of containment over sixty-four years ago, the linkages of military capability to deterrence remain applicable today to both the United States and our Allies within NATO. The familiar refrain of NSC-68, with its emphasis on military capability to deter aggression and enable a prosperous trans-atlantic security environment, can be found in the NATO Wales Summit Declaration:

Our Alliance remains an essential source of stability in this unpredictable world. ... Based on solidarity, Alliance cohesion, and the indivisibility of our security, NATO remains the transatlantic framework for strong collective defense and the essential forum for security consultations and decisions among Allies. . .As stated in the Transatlantic Declaration that we issued today, we are committed to further strengthening the transatlantic bond and to providing the resources, capabilities, and political will required to ensure our Alliance remains ready to meet any challenge. We stand ready to act together and decisively to defend freedom and our shared values of individual liberty, human rights, democracy, and the rule of law. ${ }^{81}$

${ }^{78}$ Europe Field Study Notes, September 8, 2014.

79 NSC 68, “United States Objectives and Programs for National Security,” Foreign Relations of the United States (1950), in the University of Wisconsin Digital Library, accessed March 17, 2015, http://digital.library.wisc.edu/1711.dl/FRUS, p. 255.

80“United States Objectives and Programs for National Security,” p. 244.

${ }^{81}$ Wales Summit Declaration, para. 2. 
This is a noteworthy position, and while the language of the declaration was crafted as part of a strategic communications narrative that NATO is committed to collective security, it was also a bellwether to the members of the Alliance themselves to firmly commit to the development of military capability and capacity should there be a need to take action. The ability to take action, however, is the linchpin for any kind of deterrence or coercive diplomacy, so the Alliance must have the ability to demonstrate a credible threat of force. ${ }^{82}$ At present, unfortunately, after decades of decline in defense spending and various levels of commitment to expeditionary operations, the forces of most European countries have been "hollowed out to such an extent they are unable to field corps or even divisions in some cases," so NATO and its member states are emphasizing the necessity of military readiness and capability—once again. ${ }^{83}$

The call for this action has been made on several previous occasions. NATO as an institution has and continues to advocate for prudent investment in military capability, as demonstrated through repeated initiatives and policy throughout recent years. As noted earlier, during the 2011 Munich Security Conference former Secretary General Rasmussen appealed to the Alliance to recognize and initiate the concept of "Smart Defense" in order for members to “build greater security with fewer resources but more coordination and coherence," as a means to prudently maintain and improve military capabilities to better enable collective security in a resource constrained environment. ${ }^{84}$

While Smart Defense is solid and sound policy for establishing military capability, the concept is reminiscent of classic children’s literature. First published in 1947 by Marcia Brown after the Second World War in Europe, many children have grown up reading a classic story

${ }^{82}$ Ivo H. Daalder and Michael E. O’Hanlon, Winning Ugly: NATO’s War to Save Kosovo (Washington, DC: Brookings Institute Press, 2000), 208.

${ }^{83}$ Luis Simon, “Assessing NATO’s Eastern European Flank,” Parameters 44, no. 3 (Autumn 2014), 73.

${ }^{84}$ Rasmussen, February 4, 2011. 
entitled "Stone Soup.” Most of us are probably familiar with this tale, based on French folklore, of three hungry and tired soldiers approaching a village where the peasants hid their meager rations of food upon learning of their approach. In a very wily and enterprising solution, the soldiers begin boiling a large pot of water in the town square as they profess to make soup from three small stones. The people of the village, impressed by this notion, begin contributing bits and pieces of meat and vegetables to create a meal for everyone, thus highlighting the power and importance of cooperation and what small contributions by all can produce for the greater good. ${ }^{85}$

A year after appealing for Smart Defense, then Secretary General Rasmussen, speaking to a forum gathered in Washington, DC about the development of a new strategic concept, highlighted the idea of the Connected Forces Initiative (CFI) as a critical component and example of Smart Defense:

Smart Defense is about acquiring the necessary capabilities. Connectivity is about making these capabilities work together most effectively. The Connected Forces Initiative mobilizes all of NATO's resources to strengthen the Allies' ability to work together in a truly connected way. This is particularly important as we wind down our combat operations in Afghanistan at the end of 2014. I see three areas to focus our efforts in the coming years: expanded education and training; increased exercises, especially with the NATO Response Force; and better use of technology. ${ }^{86}$

These three important focus areas of the CFI are complementary to former Defense Secretary Hagel's defense priorities of collaboration and building joint capacity with our European Allies as written in the 2014 Quadrennial Defense Review. Most recently in September 2014 at the NATO Summit in Wales, Alliance representatives reinforced the importance of CFI to maintain "an

${ }^{85}$ Marcia Brown, Stone Soup (New York, NY: Aladdin Paperbacks, 1947).

${ }^{86}$ Anders F. Rasmussen, NATO Secretary General Remarks at the Allied Command Transformation Seminar, Washington, D.C., February 28, 2012, accessed September 20, 2014, http://www.nato.int/cps/en/natolive/opinions_84689.htm. 
enhanced exercise program with an increased focus on exercising collective defense” and to ensure "the training and exercise elements of the Readiness Action Plan." ${ }^{87}$

The much publicized Readiness Action Plan was approved at the Wales Summit to "ensure that our Alliance is ready to respond swiftly and firmly to the new security challenges" that have emerged in the Twenty-first century. Elements of this plan proscribe and aspire to reassure the members of the Alliance and "adapt” the military strategic posture of NATO. ${ }^{88}$ Any degree of conventional deterrence requires the credible ability to rapidly respond against various forms of aggression. ${ }^{89}$ Toward that end, the purpose and intent of the Readiness Action Plan provides just enough specificity for planning while providing latitude for action:

It provides a coherent and comprehensive package of necessary measures to respond to the changes in the security environment of NATO's borders and further afield that are of concern to Allies. It responds to the challenges posed by Russian and their strategic implications. It also responds to the risks and threats emanating from our southern neighborhood, the Middle East and North Africa. The plan strengthens NATO's collective defense. It also strengthens our crisis management capability. The Plan will contribute to ensuring that NATO remains a strong, ready, robust, and responsive Alliance capable of meeting current and future challenges from wherever they may arise. ${ }^{90}$

In this context, the Readiness Action Plan appears to be “aimed at satisfying all of NATO's various constituencies" with emphasis on enhanced military capabilities as well as the creation of the "Very High Readiness Joint Task Force" - possibly labeled as such to separate it from the current units comprising the NATO Response Force and to indicate a renewed sense of urgency and greater degree of preparedness. ${ }^{91}$

${ }^{87}$ Wales Summit Declaration, para. 10.

${ }^{88}$ Wales Summit Declaration, para. 5-6.

${ }^{89}$ Navy Operations Concept, "Implementing the Maritime Strategy" (Washington, DC: Department of Defense, 2010), 76.

${ }^{90}$ Ibid.

${ }^{91}$ Deni, 60-62. 
Although there is effort to identify both of these force capability structures as distinct, there is continued emphasis on interoperability among all NATO forces. Without specifically citing interoperability, the latest 2010 NATO Strategic Concept addresses the necessity of fielding "military forces able to operate together in any environment; that can control operations anywhere through its integrated military command structure.”92 Similar to the Strategic Concept, but with greater clarity, the 113 pages of the 2014 Wales Summit Declaration reinforced the need for interoperability within the Alliance and formally adopted a “comprehensive Partnership Interoperability Initiative” to sustain the progress established during operations in Afghanistan and to "enhance our ability to tackle security challenges together with our partners." ${ }^{93}$ Several civilian and military representatives at NATO agree that interoperability, through the goals of the Connected Forces Initiative, is the number one priority for maintaining the continued relevance of NATO and that "increasing capability and readiness through training and exercises is where we will make our money." ${ }^{94}$ NATO has and continues to focus on and increase its level of interoperability among member states. The Alliance maintains networks of officers for militaryto-military cooperation among countries, maintains NATO Standards and operating procedures, shares intelligence and routinely collaborates in training and exercises—all in the name of increased interoperability. ${ }^{95}$

While the Very High Readiness Joint Task Force and other force enhancements, along with the push for increased interoperability, were instituted to support readiness, the NATO Framework Nations Concept was endorsed as another means to promote increased military capability. This concept, which was a German proposal endorsed by NATO defense ministers in

${ }^{92}$ NATO Strategic Concept, 2010, 36.

${ }^{93}$ Wales Summit Declaration, paras. 9, 63, and 88.

${ }^{94}$ Europe Field Study notes, September 11, 2014.

${ }^{95}$ Kashmeri, 18. 
June 2014, builds upon Smart Defense and the Connected Forces Initiative to encourage "groups of allies to work together to develop, acquire, operate and maintain military capabilities." ${ }^{\text {"6 }}$ Led and facilitated by a "framework nation," other allies will commit to "working systematically together, deepening and intensifying their cooperation in the long term. . .to address Alliance priority areas across a broad spectrum of capabilities.” In turn, this is expected to demonstrate a "willingness to do more for our common security" among the members of the Alliance and "improve the balance of the provision of capabilities between the United States and European Allies." ${ }^{97}$ In other words, we remain committed to making "stone soup” on an international level as a recipe for increased military capability.

$\underline{\text { Will }}$

Along with the desired objective for increased military capability, though, must be a willingness to use it. The variable of will is difficult to conceptualize, as it fluctuates across a spectrum of context and circumstances. One indicator of will within the Alliance will certainly be the level of commitment shown in implementing the various measures of the Wales Summit declaration itself. Only a week removed from the consensus and publication of the declaration, some representatives of the Alliance were already calling its effectiveness into question. “Declarations are good,” said one European military representative, "but everything depends on implementation.”98 Implementation of the declaration will be difficult to assess in some areas, but one true and verifiable indicator of commitment will be defense spending. In an effort to "reverse the trend of declining defense budgets, to make the most effective use of our funds and to further a more balanced sharing of costs and responsibilities,” the Alliance members agreed to maintain

${ }^{96}$ Deni, 60-62.

${ }^{97}$ Wales Summit Declaration, para. 67.

${ }^{98}$ Europe Field Study Notes, September 11, 2014. 
or halt the decline of their respective defense spending, as well as military research and development activities. While it is disappointing that members were given a decade to ensure their expenditures match the $2 \%$ GDP commitment, this is a decent step toward universal commitment to the relevance of NATO in maintaining collective security. ${ }^{99}$

Putting “one’s money where their mouth is” may be an oversimplification, but it cannot be overlooked as a component of national will. Budgets and defense spending reflect the will of society, and "an alliance that is shaped largely by domestic public opinion and narrow domestic political interests and benefits does not portend well for an alliance that seeks strategic consensus." ${ }^{100}$ If there is not enough collective will to agree on spending priorities, it begs the question as to whether or not a member will have enough political capital to ensure larger obligations are satisfied within the Alliance, up to and including the implementation of Article Five of the Washington Treaty and the subsequent military action it may require.

From an Alliance perspective, these obligations are critical to the relevance of NATO, as the actions of each member state profoundly influences the others. In terms of strategy, it has been notably stated that "deterrence relies on the credibility of the threat it invokes.” ${ }^{101}$ Lawrence Freedman places this idea of credibility and will within the context of national interests and NATO operations:

As the conflict develops, its character will change and adjustments will have to be made. In times such as these, states are obligated to come clean on what is of central importance to them and what is peripheral. These interests may well be reappraised continually in the light of changing circumstances, with the costs and risks of attending to one set of interests constituting and interest in themselves, and new interests will develop beyond those which prompted the crisis in the first

${ }^{99}$ Wales Summit Declaration, para. 14.

${ }^{100}$ Rachel A. Dicke, et al. "NATO Burden-sharing in Libya: Understanding the Contributions of Norway, Spain and Poland to the War Effort,” The Polish Quarterly of International Affairs 22 no. 4 (2013), 53.

${ }^{101}$ Hew Strachan, “Strategy and the Limitation of War," Survival 50, no. 1 (FebruaryMay 2008), 40. 
place. In 1999 in Kosovo, for example, because it was NATO that issued the threat rather than individual countries, the credibility of the organization as a security provider for Europe was soon in question. Individual states had to consider the implications of walking away from the conflict with Serbia for the integrity of this vital organization. ${ }^{102}$

Freedman's analysis is supported by the work of Samuel Huntington, who offers the adage that "weak, unstable, and adventurous allies are a liability rather than an asset." ${ }^{103}$ For NATO as a relevant organization, the passage highlights the importance of credibility and will.

As one European military representative summarized this point, "if you fail once in maintaining the credibility of Article Five, NATO is over." ${ }^{104}$ Article Five is the centerpiece for commitment to collective defense within the North Atlantic Treaty, so in addition to enabling military consultation and defense cooperation among the member states, it also serves as a "potential deterrent against would-be enemies of the allies and a source of reassurance should future threats develop." ${ }^{105}$ Regardless, Russian aggression in the Ukraine has caused a "schism" within the Alliance, requiring additional "reassurance measures” to keep the Alliance together. ${ }^{106}$ One individual from the Ukraine, while expressing gratitude to NATO and its member states for continued support and remaining committed to the implementation of NATO standards within its military structure, was equally clear in stating "there is no stability in the Twenty-first century and there are no instruments to protect us” despite the fact that his country gave up nuclear weapons in 1994 in exchange for "guaranteed security.” 107

${ }^{102}$ Lawrence Freedman, Deterrence (Cambridge, UK: Polity Press, 2004), 113-114. 1959), 68.

${ }^{103}$ Samuel Huntington, The Soldier and the State (Cambridge, MA: The Belknap Press,

${ }^{104}$ Europe Field Study Notes, September 11, 2014.

105 Stanley R. Sloan, Permanent Alliance?: NATO and the Transatlantic Bargain from Truman to Obama (New York: Continuum, 2010), 8.

${ }^{106}$ Europe Field Study Notes, September 11, 2014.

${ }^{107}$ Ibid. 
Despite the fact that Ukraine, and Georgia, are not members of NATO, this idea of guaranteed security, or the lack thereof, is not lost among other members of the Alliance especially those in Central-Eastern Europe. As one representative serving in the Baltic Defense College has stated:

The umbrella of NATO security has caused schizophrenia among policy makers in our country. Some say we are covered, and some say we are not, so we don't put all our eggs in one basket. Regardless, our center of gravity is time: we [armed forces] are a speed bump to buy more time for NATO to invoke Article Five. ${ }^{108}$

This attitude is likely more prevalent than many of us wish to acknowledge, primarily because it centers around willingness for action. With the litany of reassurance measures taken by NATO, along with the Declaration from the Wales Summit, it is possible that some of these worries have been put at ease, at least for the time being. Perhaps the consensus and actions of the Alliance are effective enough to "establish a line and convince the opponent that there his gains must stop." What we do know is that "success of deterrence depends on whether the many individuals who hold keys to war and peace think coherently” in terms of maintaining the capability and will to hold the established line. ${ }^{109}$ If the Alliance is to continue to serve as "a security anchor in a sea of political turbulence,” the relevance and continued prosperity of NATO will depend on it. ${ }^{110}$

${ }^{108}$ Europe Field Study Notes, September 5, 2014.

${ }^{109}$ Fred C. Ikle, Every War Must End, ${ }^{\text {nd }}$ rev. ed. (New York, NY: Columbia University Press, 2005), 118.

${ }^{110}$ Papacosma, et al, 49. 


\section{Continued Relevance and “A Way” Ahead}

Regional and global trends in the security environment, coupled with increasing fiscal austerity, will make it imperative that the United States adapt more quickly than it has in the past and pursue more innovative approaches and partnerships in order to sustain its global leadership role.

--Quadrennial Defense Review 2014

In discussing “NATO at Fifty,” Lawrence Kaplan posed several questions about the continued existence and relevance of the Alliance at the end of the Cold War. Would NATO dissolve in the absence of threat from the Soviet Union? Would NATO survive through "bureaucratic inertia” and continue as “a structure without meaning or purpose?” As of his writing in 1999 and answering his previous questions, Kaplan declared that NATO’s “demise has been warded off with mixed success so far" and is very much "alive even as it still seeks a rationale for its role in the future." ${ }^{111}$ Recent trends indicate "citizens of Europe and of North America continue to have warm feelings for NATO as the embodiment of the transatlantic security relationship.” ${ }^{112}$ As the world becomes increasingly interdependent, the continuation of this favorable attitude will likely be viewed through the lens of security and economic interests from a national perspective. As mentioned in the introduction for the scope of this paper, relevance is defined as NATO's ability to achieve its raison d'être as a defensive alliance to “resist aggression, whatever its source.” 113 If security and economic outlooks remain favorable, with NATO seen as an essential enabler of that environment, then the Alliance will continue to be perceived and accepted as value-added and relevant. Beyond this rationale for members to maintain NATO, adversaries must view NATO as a capable deterrent in order to be relevant.

${ }^{111}$ Lawrence Kaplan, The Long Entanglement: NATO’s First Fifty Years, 203-204.

112 Kashmeri, 18.

113 Layne, 89-90. 
In questioning the relevance of NATO, we have examined the current challenges facing the Alliance to assist in determining utility and necessity. From there we proceeded to review deterrence as a combination of capability and political will, emphasizing that how we demonstrate each will remain the linchpin to ensuring relevance of the Alliance. Within this view of challenges, capabilities and willingness to act, what policies and initiatives should be emphasized, pursued or discarded as we move forward in the twenty-first century to keep NATO viable and relevant? This question will be addressed in four distinct, but converging areas of interest with associated recommendations: firmly establish and emphasize that NATO's strategic priority is collective defense; implementation of the Wales Summit Declaration reassurance measures, with US reassurance of a long-term and vital interest in NATO and European security; NATO withdrawal from the NATO-Russia Founding Act; and indefinite suspension of the "Open Door” policy of NATO enlargement.

\section{Collective Defense as a Strategic Priority}

It has already been suggested that the leaders of several member states within the Alliance, especially those in Central-Eastern Europe, have concerns regarding the actual protection offered by Article Five of the North Atlantic Treaty. NATO has initially addressed these fears through continued use of strategic communications to reinforce reassurance measures taken by the Alliance, such as placing company-sized forces on the ground for training and military-to-military cooperation. The 2010 NATO Strategic Concept articulated collective defense, crisis management, and cooperative security as the three core "pillars of security" tasks for the Alliance. For collective defense in particular, the Strategic Concept states:

NATO members will always assist each other against attack, in accordance with Article Five of the Washington Treaty. That commitment remains firm and binding. NATO will deter and defend against any threat of aggression, and 
against emerging security challenges where they threaten the fundamental security of individual Allies or the Alliance as a whole. ${ }^{114}$

The Alliance emphasized commitment to these core tasks in the Wales Summit Declaration when they purposefully, during “a pivotal moment in Euro-Atlantic security,” stood together in "reaffirming our strong commitment to collective defense and to ensuring security and assurance for our Allies.”115 This was a necessary and much appreciated gesture, as NATO must continue to emphasize collective defense via Article Five as the cornerstone of the Alliance with a priority over all other NATO operations and interests. With NATO’s ISAF mission reaching a conclusion, combined with recent Russian activity in the Ukraine, now is the time to refocus Alliance energy on exercises, interoperability, and readiness within the physical confines of Europe to keep NATO as a relevant deterrent to outside aggression. In doing so, however, we must heed the advice of the former Supreme Allied Commander of NATO, Admiral James Stavridis, and avoid putting the Alliance in "a very defensive crouch inside the borders of the North Atlantic." ${ }^{116}$ A prioritization of Europe first, though, over other global actions or initiatives should demonstrate will and alleviate fears of inaction among those NATO states on the geographic periphery of the Alliance.

\section{$\underline{\text { US and NATO Reassurance }}$}

Through its declarations, NATO has begun the process of prioritizing its efforts on collective defense within Europe. However, there remains much to be accomplished during the implementation of the robust measures delineated during the Wales Summit. As an integral member of NATO, the United States has a great level of responsibility in demonstrating our permanent interest in the Alliance and the security of Europe. We start that process by

\footnotetext{
${ }^{114}$ NATO Strategic Concept 2010, 7.

${ }^{115}$ Wales Summit Declaration, paras. 1 and 3.

116 James Stavridis, The Accidental Admiral: A Sailor Takes Command at NATO (Annapolis, MD: Naval Institute Press, 2014), 174.
} 
maintaining our strength and credibility as a nation. As summarized by historian Walter McDougal: "If the United States remains strong, it will attract allies and clients as a light attracts moths, whether or not some multilateral body is involved. If the United States becomes feeble, no amount of begging, bribing, or appeals to international norms will induce others to honor our interests or stand by us in danger." ${ }^{117}$ With that strength and role as a leader of the world comes obligation as well. The late Ambassador Richard Holbrooke, no stranger to the operational requirements for NATO, reinforced this belief when he expressed that "the world's richest nation . . cannot simply make worthy appeals to conscience and call on others to carry the burden. The world will look to Washington for more than rhetoric the next time we face a challenge to peace.”118

Our rhetoric must be clarified and substantial if we are to maintain credibility in demonstrating our capability and will as a nation. After leading the Kosovo Campaign for NATO, General Wesley Clark wrote that "credibility is the ultimate measure of value for states and international institutions.” ${ }^{119}$ Despite all the United States has done for security in Europe, the much-debated "pivot to the Pacific” strategy sent shock-waves through most European capitals within the Alliance. The problem with the language of "pivot” is that it implies "turning away" from one area to address another, which is not the intent in maintaining our interest in Europe. Although alternate language of "re-balance” has replaced the use of "pivot," one high-level official in Washington summed it up well when he stated that "We did a pretty woeful job in explaining what the Pacific Pivot is, especially to our European Allies.” ${ }^{120}$ The issues with explanation are compounded by a universal understanding of actions within a resource-

\footnotetext{
${ }^{117}$ McDougal, 218.

${ }^{118}$ Holbrooke, 372.

${ }^{119}$ Clark, 457.

${ }^{120}$ Washington Field Study Notes, July 27, 2014.
} 
constrained environment. “However powerful America is,” according to Henry Kissinger, “no country has the capacity to impose all its preferences on the rest of mankind; priorities must be established.”121 In this case, however, actions are more important than words.

The United States, along with other NATO members, have taken action to reassure other members of the Alliance that they will not be alone in addressing Russian aggression and the other threats to Europe. The reassurance measures established at the Wales Summit complement ongoing rotation of forces, mostly at the company-level, for training and presence in CentralEastern Europe. Reaffirming our own national priorities and interests, a senior officer speaking at Fort Leavenworth stressed the importance of this type of partnership and presence with our Allies as a "competitive advantage" that we must continue and protect. ${ }^{122}$ The fortunate fact is that the United States is already postured and resourced to maintain this competitive advantage with NATO and Europe through the Joint Multinational Training Center (JMTC) based in Grafenwoehr, Germany.

Throughout the past decade, the JMTC has been instrumental in preparing US and multinational units for service abroad in operations in Iraq, Afghanistan, and Kosovo. The state of the art facilities and equipment, maneuver area, and most importantly its proximity to allies and partners in Europe have made the JMTC an affordable, accessible, and economical location of choice to train, validate and certify Coalition units to enable their operational success. Global challenges have offered ample occasions to share hardship, but as the United States and NATO completed the ISAF mission at the end of 2014, NATO shifted its emphasis from operational engagement to operational preparedness. This presents an unprecedented opportunity for education and training with our European partners at the JMTC. We can continue to capitalize on

${ }^{121}$ Henry Kissinger, Diplomacy (New York, NY: Simon and Schuster, 1994), 812.

122 Briefing notes, Combined Arms Center, Fort Leavenworth, Kansas, November 12, 2014. 
the relationships and sustain the partnerships established during a time of war, but with latitude to shift from an Operational Environment-specific "readiness exercise” to a decisive action “leadership laboratory” with first-class, realistic training against a near-peer competitor tailored to specific objectives and desired outcomes.

While a majority of partnered education and training occurs at JMTC, a tremendous amount of this effort occurs on the home soil of our allies and partners. Enabled by geographical proximity, a majority of our senior experienced trainers travel to various countries to conduct Leader Training Programs, specialty training, training center development and military-tomilitary cooperation events. This “expeditionary” capability and ability to export our training expertise has greatly strengthened our partnership with other nations and sets the conditions for continued participation in multinational and multi-echelon named exercises to reinforce interoperability, readiness, and collective security. Enabled by geographical proximity and personal partnership in Europe, the “Combined Resolve” series of exercises, for example, has focused on improving NATO interoperability (nine or more different nations per rotation) by integrating warfighting functions, personnel, and doctrine; while integrating the EUCOM Army Contingency Response Force company to demonstrate our ability to rapidly mobilize and integrate our forces across a theater of operations to support our allies with a responsive combat force. More importantly, a continued emphasis on training, exercises, and partnership helps demonstrate American commitment to the relevance of NATO and the collective security of Europe.

An even more tangible demonstration of permanent interest in NATO and Europe could be demonstrated through the manning or establishment of bases in Central-Eastern European countries such as Poland, Estonia and others as necessary. Individuals from Poland have made no secret of their desire to have a "permanent United States presence” within their country, and leaders within Estonia have agreed to exceed spending two percent of the GDP on defense to 
contribute to US basing presence within their borders. ${ }^{123}$ As already stated, the United States is rotating forces in these countries and others in the area as part of NATO reassurance measures to collective security, and plans continue for Regional Alignment Forces to maintain that persistent presence. Regardless, long-term basing in these areas is worthy of consideration. While it is generally accepted that regionally aligned forces will be financially cheaper in the long term, as of the end of 2014 there has been no modeling or analysis to validate that claim. At least one general officer has stated that the "rotational model" will ultimately be more expensive than forward basing, and expressed concerns about the ability to maintain quality relationships and effective partnership with a constant rotation of leaders and Soldiers. ${ }^{124}$

\section{Withdrawal from the NATO-Russia Founding Act}

For either the basing or the rotation courses of action, however, it is important to balance presence and provocation—specifically toward Russia. Toward that end, NATO should formally withdraw from the 1997 Founding Act for the NATO-Russian Council to better provide options and freedom of maneuver for force posturing within the Alliance. The Founding Act was not vigorously addressed in the 2010 NATO Strategic Concept beyond its recognition as a contract of “strategic importance,” especially in terms of maintaining “the respect of democratic principles and the sovereignty, independence and territorial integrity of all states in the Euro-Atlantic area.” ${ }^{25}$ To be fair, the Founding Act was not controversial during the time the Group of Experts were charged with informing the revision of the new Strategic Concept, and the United States and NATO were in a period of "reset" with Russia. During the Wales Summit that changed, as the

${ }^{123}$ Europe Field Study Notes, September 6, 2014. Any valid consideration of US basing would be an issue of diplomatic involvement and importance.

${ }^{124}$ Forces Command Field Study Notes, December 11, 2014 and briefing notes at CAC, November 12, 2014.

${ }^{125}$ NATO Strategic Concept, 2010, 29-30. 
Alliance declared that "Russia has breached its commitments [of the NATO-Russia Founding Act], as well as violated international law, thus breaking the trust at the core of our cooperation.”126

Within this new outlook toward Russia and as a reaction to the transition from partnership to adversary, it is time to move beyond demonstration of good will and the façade of cooperation in favor of prudent measures for collective security as we "adapt to have a response to increased uncertainty on our periphery” with Russia. ${ }^{127}$ Committing United States or NATO forces indefinitely in Central-Eastern European member states would send a powerful and articulate message that the Alliance means to maintain a posture of collective defense within Europe. This is seen by some NATO members, such as Germany, as a violation of the 1997 Founding Act language where "NATO reiterates that in the current and foreseeable security environment, the Alliance will carry out its collective defense and other missions by. . . reinforcement rather than by additional permanent stationing of substantial combat forces.” ${ }^{128}$ Much like the Budapest Agreement to assist in the security of the Ukraine, however, the Founding Act is not a treaty nor legally binding. While it is arguably true that member states should keep their word in honoring such agreements, it should also be noted that the Founding Act has already been violated by Russia through its own aggression so it is no longer a valid agreement to uphold. As of this writing, Alliance exercises with Russia have been canceled and the work of the NATO-Russian Council has been suspended although "political channels of communication remain open.” ${ }^{129}$ The next logical step is to take prudent measures, such as

\footnotetext{
${ }^{126}$ Wales Summit Declaration, para. 21.

${ }^{127}$ Europe Field Study Notes, September 11, 2014.

${ }^{128}$ Founding Act on Mutual Relations, Cooperation and Security between NATO and the Russian Federation, signed in Paris, France, May 27, 1997.

${ }^{129}$ Wales Summit Declaration, para. 22.
} 
forward basing in Central-Eastern Europe, to maintain collective security and keep the Alliance relevant.

That is not to say that Russia is our enemy. The Wales Summit Declaration makes it very clear that the Alliance "does not seek confrontation and poses no threat to Russia." ${ }^{130}$ This statement, while mostly correct and well intentioned, does transmit a garbled message if taken with paragraph ninety-two of the Wales Summit Declaration to maintain the “Open Door” Policy of NATO enlargement. According to noted political scientist John Mearsheimer, "the United States and its European allies share most of the responsibility for the crisis” in the Ukraine through our continued policy of NATO enlargement. ${ }^{131}$ Putin’s action in response to Ukrainian outreach to NATO and the EU should come as no surprise, especially after the 2008 invasion of Georgia where "the Russians were [also] sending a warning to other governments in Central Asia (and Ukraine) about the risks of trying to integrate with NATO.” ${ }^{132}$

\section{$\underline{\text { Suspension of the "Open Door" Policy }}$}

The Alliance must move beyond the “Open Door” rhetoric used in the 2010 NATO Strategic Concept and the 2014 Wales Summit Declaration to provide transparency about membership enlargement. There is currently a divided mentality within NATO regarding expansion of membership, as many states "new” to the Alliance desire more members, while other member states believe that further enlargement could be counter-productive and antagonistic. Realistically, further enlargement of NATO, especially along the eastern periphery of Europe and bordering Russia, is problematic. Regardless of its consensus position, NATO must genuinely enable aspiring nations through continued partnership and cooperation without

${ }^{130}$ Wales Summit Declaration, para. 23.

131 John J. Mearsheimer, "Why the Ukraine Crisis is the West's Fault: The Liberal Delusions that Provoked Putin,” Foreign Affairs 93, no. 5 (September/October 2014), 77. ${ }^{132}$ Gates, 168. 
making promises where there is no political will to deliver. To feign membership action without will creates false hope, loss of credibility, and a perception of weakness against Russian activity, especially within countries mired in "frozen conflict." ${ }^{133}$ While some argue that changing the NATO “Open Door” policy at this late stage of development would critically damage both US and Alliance credibility around the world, it can also be argued that the costs of maintaining a "misguided strategy" could be even more damaging, as "there is no reason that the West has to accommodate Ukraine if it is bent on pursuing a wrong-headed foreign policy, especially if its defense is not a vital interest.”134

The proverbial loophole for avoiding enlargement, demonstrating a lack of vital interest in both spirit and language to deny aspiring nations membership within NATO at this time, can be found in the text of the Wales Summit declaration itself:

NATO's door will remain open to all European democracies which share the values of our Alliance, which are willing and able to assume the responsibilities and obligations of membership, which are in a position to further the principles of the Treaty, and whose inclusion will contribute to the security of the North Atlantic area. ${ }^{135}$

It can logically and credibly be interpreted by anyone that granting NATO membership to the Ukraine, Georgia, or any other nation mired in frozen conflict or within the near-abroad of Russia will fail to contribute to Alliance security. On the contrary, most members of NATO are not going to risk having to enter a conflict that is not in their own best interest, as evidenced by a lack of willingness by any nation thus far to rush to the defense of the Ukraine. Since we have already effectively closed the door of NATO enlargement, denouncement of further Alliance expansion along the eastern periphery of Europe, beyond formalized Partnership that currently exists, could provide a diplomatic advantage in securing a lasting peace with the Russians. Such a condition

${ }^{133}$ Europe Field Study Notes, September 11, 2014.

${ }^{134}$ Mearsheimer, 87-88.

${ }^{135}$ Wales Summit Declaration, para. 92. Emphasis added in italics by the author. 
could also serve as the "carrot" to offset the "stick" used to implement forward basing within the territory of current members of the Alliance.

\section{Conclusion}

Regardless, enlargement and how to address the Founding Act, along with other difficult choices and challenges will undoubtedly threaten the relevance of the Alliance for years to come. It is fortunate, however, that the leaders of the Alliance have identified and acknowledged these challenges. More importantly, initial actions established by the publication of the Wales Summit Declaration have indicated that NATO is committed to standing firm against these challenges. If the Alliance can successfully implement the aspirations of the Wales Summit then most of the challenges can be utilized as opportunities to focus NATO on a course of relevance for the Twenty-first century in maintaining collective defense against the various streams of threat that oppose the Alliance. As former Secretary of Defense Hagel noted at the Munich Security Conference in 2014, “The challenges and choices before us will demand leadership that reaches into the future without stumbling over the present.” ${ }^{136}$ What NATO cannot afford to do, whether burdening sharing commitments in the Wales Summit Declaration are honored or not, is remain wedded to business as usual in terms of enlargement and keeping the NATO-Russia Founding Act on life support.

Actions in regard to both the Founding Act and the issue of enlargement will be largely determined by the critical challenge not addressed by the Wales Summit, Readiness Action Plan or any other document produced by NATO Headquarters—consensus. Despite its associated challenges, though, consensus may very well be the most critical component of the Alliance in keeping relevance momentum moving forward. There may be a time, based on continued failure

${ }^{136}$ Chuck Hagel, US Secretary of Defense Remarks, 2014 Munich Security Conference, Munich Germany, February 1, 2014. 
of member states to meet their financial and resource commitments, that NATO move to some form of consensus matrix or levels of consensus determined by those members who pay for their seat at the table. While such drastic action would send a clear message, it would also be unfortunate and counter-productive to the spirit that has lived within the Alliance since its founding. It would be much preferred to maintain the current system of consensus, where members that do not want to support an action "on the record" can merely avoid "breaking silence” and allow the action to proceed without their support or disapproval. There is no need to fundamentally change something that works. Ultimately, if NATO goes too far off the course of what a member can tolerate the nation can "vote with its feet" and leave the Alliance.

Perhaps that is the great testament to the continued relevance of the Alliance-that no member has ever fully left NATO and the “transatlantic bonds were never severed,” despite Professor Kaplan’s notable observation that "no year in the Cold War had passed without revelations of strains between the United States and its European Allies; some were minor, others serious.” ${ }^{137}$ Under Article Thirteen of the North Atlantic Treaty a member has the option to “cease to be a Party one year after its notice of denunciation,” but thus far no member has felt compelled to take that step to find a way out of the Alliance. ${ }^{138}$ Futhermore, there is "no serious political force on either side of the Atlantic that would advocate NATO’s dissolution.” ${ }^{139}$ Even France, who caused a crisis within NATO in the 1960s by withdrawing from the Alliance’s integrated command structure, has returned into the NATO military structure and ended " 40 years of ambivalence vis-à-vis the Alliance." ${ }^{140}$ It is the ability of leaders of like-minded nations to sit 150.

${ }^{137}$ Lawrence Kaplan, NATO Divided, NATO United: The Evolution of an Alliance, 149-

138 Ibid.

139 Bebler, 173.

${ }^{140}$ Ibid. 
around the table, in periods of prosperity and in times of great difficulty, that make the Alliance both relevant and necessary.

The Alliance was born out of necessity to offset the power of would-be aggressors, both in deterring attack and for mutual support were that deterrence to fail. Later, in 1967, the Harmel Report reaffirmed this mission to "maintain adequate military strength and political solidarity to deter aggression” and “defend the territory of member countries if aggression occurs.” ${ }^{141}$ Today, the US must remain "convinced that political and military cooperation with the European Allies makes an important contribution” to our own national interests, while "Europeans must believe that contributing to international security efforts alongside the United State will produce influence for Europe over US decisions that affect their security." ${ }^{142}$ For the US, it remains noteworthy that "Europe is strategically located on an important piece of real estate” and that "NATO’s bases are not 'bastions of the Cold War'” but rather "the forward operating bases of the twenty-first century." ${ }^{143}$ A forward presence in Europe, along with the relationships that come from our ability to "live, train, and operate alongside many capable allies and partners every day" directly enable access and "linkages to increasingly unstable and unpredictable regions vital to US national security interests." ${ }^{144}$ If that fact alone is not an adequate case for continued relevance, then we must also remember another key task outlined in the Harmel report, where it was the responsibility of NATO to provide an "effective forum and clearing house for the exchange of information and views” that has been the greatest single-contributor to its effectiveness. ${ }^{145}$ This

${ }^{141}$ NATO Headquarters, “The Future Tasks of the Alliance,” The Harmel Report, December 13, 1967, para. 5.

142 Sloan, 289.

${ }^{143}$ Stavridis, 168.

${ }^{144}$ Donald M. Campbell, Jr. and Michael T. Whitney, “Assurance in Europe: Why Relationships Matter,” Military Review 94 no. 6 (November-December 2014), 8.

145 The Harmel Report, para. 7. 
task remains unchanged today, and will remain essential to the relevance of NATO as we move forward in the twenty-first century. 


\section{Bibliography}

Albright, Madeleine, et al. NATO 2020: Assured Security: Dynamic Engagement, Analysis and Recommendations of the Group of Experts on a New Strategic Concept for NATO. Brussels, Belgium: NATO Public Policy Division, May 17, 2010.

Allison, Roy, Margot Light and Stephen White. Putin's Russia and the Enlarged Europe. London: Chatham House, 2006.

Auerswald, David and Stephen Saideman. NATO in Afghanistan: Fighting Together, Fighting Alone. Princeton, NJ: Princeton University Press, 2014.

Author’s Field Study Notes, Travel to Washington, DC, July 27-30, 2014.

------ Travel to Poland, Estonia, Germany and Belgium, September 1-12, 2014.

------ Briefing Notes, Combined Arms Center, Fort Leavenworth, KS, November 12, 2014.

------ Travel to United States Forces Command, Fort Bragg, NC, December 11, 2014.

Aybet, Gülnur, and Rebecca R. Moore, ed. NATO in Search of a Vision. Washington, DC: Georgetown University Press, 2010.

Bebler, Anton ed. NATO at 60: The Post-Cold War Enlargement and the Alliance's Future. Amsterdam, NLD: IOS Press, 2010.

Binder, David. “Greece, Turkey, and NATO.” Mediterranean Quarterly 23, no.2 (2012): 95-106.

Blair, Tony. A Journey: My Political Life. New York, NY: Alfred A. Knopf, 2010.

Brown, Marcia. Stone Soup. New York, NY: Aladdin Paperbacks, 1947.

Bugajski, Janusz, ed. Toward an Understanding of Russia: New European Perspectives. New York: Council on Foreign Relations, 2002.

Bugajski, Janusz and Ilona Teleki. America's New Allies: Central-Eastern Europe and the Transatlantic Link. Washington, DC: Center for Strategic and International Studies, 2006.

Campbell, Donald M. Jr. and Michael T. Whitney. “Assurance in Europe: Why Relationships Matter.” Military Review 94 no. 6 (November-December 2014): 5-10.

Casey, George. Strategic Reflections. Washington, DC: National Defense University Press, 2012.

Clark, Wesley K. Waging Modern War. New York: Public Affairs, 2001.

Clinton, William J. "Remarks at a signing ceremony for the NATO-Russia Founding Act in Paris, France.” Weekly Compilation of Presidential Documents 33, i.22 (June 2, 1997): 780782.

Cook, Martin L. The Moral Warrior: Ethics and Service in the US Military. Albany, NY: State University of New York Press, 2004.

Daalder, Ivo H. and Michael E. O’Hanlon. Winning Ugly: NATO’s War to Save Kosovo. Washington, DC: Brookings Institution Press, 2000.

Daalder, Ivo et al. Group of Policy Experts Report to the NATO Secretary General. "Collective Defense and Common Security: Twin Pillars of the Atlantic Alliance”. June 2014. 
Deni, John R. “NATO’s New Trajectories after the Wales Summit.” Parameters 44, no. 3 (Autumn 2014): 57-65.

Dicke, Rachel A., et al. "NATO Burden-sharing in Libya: Understanding the Contributions of Norway, Spain and Poland to the War Effort." The Polish Quarterly of International Affairs 22 no. 4 (2013): 29-53.

Founding Act on Mutual Relations, Cooperation and Security between NATO and the Russian Federation, Paris, France, May 27, 1997.

Freedman, Lawrence. Deterrence. Cambridge: Polity Press, 2004.

------. Strategy: A History. New York: Oxford University Press, 2013.

Gates, Robert M. Duty: Memoirs of a Secretary at War. New York: Alfred A. Knopf, 2014.

Hagel, Chuck. United States Secretary of Defense Remarks to the 2014 Munich Security Conference, Munich, Germany, February 1, 2014. Accessed September 20, 2014. http://www.defense.gov/Speeches/Speech.aspx?SpeechID=1828.

Harrison, Ross. “Towards a Regional Strategy Contra ISIS.” Parameters 44, no. 3 (Autumn 2014): 37-46.

Herspring, Dale R. The Pentagon and the Presidency: Civil-Military Relations from FDR to George W. Bush. Lawrence, KS: University Press of Kansas, 2005.

Hillison, Joel R. Stepping Up: Burden Sharing by NATO’s Newest Members (Carlisle, PA: Strategic Studies Institute, November 2014).

Holbrooke, Richard. To End a War. New York: The Modern Library, 1999.

Howorth, Jolyon, and John T.S. Keeler, eds. Defending Europe: The EU, NATO, and the Quest for European Autonomy. New York: Palgrave Macmillan, 2003.

Huntington, Samuel. The Soldier and the State. Cambridge, MA: The Belknap Press, 1959.

Ikle, Fred Charles. Every War Must End. Second Revised Edition. New York: Columbia University Press, 2005.

Kaplan, Lawrence S. The Long Entanglement: NATO’s First Fifty Years. Westport, CT: Praeger, 1999.

------. NATO Divided, NATO United: The Evolution of an Alliance. Westport, CT: Praeger, 2004.

Kashmeri, Sarwar A. NATO 2.0: Reboot or Delete? Washington, DC: Potomac Books, 2010.

Kissinger, Henry. Diplomacy. New York, NY: Simon and Schuster, 1994.

Kotter, John P. Power and Influence. New York, NY: The Free Press, 1985.

Layne, Christopher. The Peace of Illusions: American Grand Strategy from 1940 to the Present. Ithaca, NY: Cornell University Press, 2006.

Lind, Michael. The American Way of Strategy. New York, NY: Oxford University Press, 2006.

March, James G. A Primer on Decision Making: How Decisions Happen. New York: The Free Press, 1994. 
Masters, Jonathan. "North Atlantic Treaty Organization (NATO),” Council on Foreign Relations Backgrounder, August 5, 2014.

McDougall, Walter A. Promised Land, Crusader State: The American Encounter with the World Since 1776. Boston: Houghton Mifflin Company, 1997.

Mearsheimer, John J. "Why the Ukraine Crisis is the West's Fault: The Liberal Delusions that Provoked Putin.” Foreign Affairs 93, no. 5 (September-October 2014): 77-89.

National Security Strategy 2015. The White House. Washington, DC: February 1, 2015

NATO Headquarters, Allied Command Transformation. "Building the Alliance's New Strategic Concept: Allied Command Transformation Reflections.” Norfolk, VA: February 2010.

NATO Headquarters, “The Future Tasks of the Alliance,” The Harmel Report. December 13, 1967.

Navy Operations Concept, “Implementing the Maritime Strategy” Washington, DC: Department of Defense, 2010.

Nazemroaya, Mahdi D. The Globalization of NATO. Atlanta: Clarity Press, 2012.

Olson, Mancur. The Logic of Collective Action: Public Goods and the Theory of Groups. Cambridge, MA: Harvard University Press, 1971.

Papacosma, S. Victor, Sean Kay, and Mark R. Rubin, eds. NATO after Fifty Years. Wilmington, DE: Scholarly Resources, 2001.

Putin, Vladimir. Address to the 2007 Munich Security Conference, Munich, Germany, February 10, 2007.

Quadrennial Defense Review 2014. US Department of Defense. Washington, DC: March 4, 2014.

Rasmussen, Anders Fogh. NATO Secretary General Keynote Address at the 2011 Munich Security Conference, Munich, Germany, February 4, 2011. Accessed September 20, 2014. http://www.nato.int/cps/en/natolive/opinions_70400.htm.

------. NATO Secretary General Remarks at the Allied Command Transformation Seminar, Washington, DC, February 28, 2012. Accessed September 20, 2014. http://www.nato.int/cps/en/natolive/opinions_84689.htm.

Renz, Bettina. "Russian Military Capabilities after 20 Years of Reform.” Survival 56, no. 3 (JuneJuly 2014): 61-84.

Rumsfeld, Donald. Known and Unknown. New York: Sentinel, 2011.

Sakwa, Richard. “'New Cold War' or Twenty Years' Crisis? Russia and International Politics.” International Affairs 84, no. 2 (2008): 241-267.

Simon, Luis. “Assessing NATO’s Eastern European Flank.” Parameters 44, no. 3 (Autumn 2014): 67-79.

Sloan, Stanley R. Permanent Alliance?: NATO and the Transatlantic Bargain from Truman to Obama. New York: Continuum, 2010.

Stavridis, James. The Accidental Admiral: A Sailor Takes Command at NATO. Annapolis, MD: Naval Institute Press, 2014. 
Strachan, Hew. "Strategy and the Limitation of War." Survival 50, no. 1 (February-May 2008): 31-54.

Strassler, Robert B. Ed. The Landmark Thucydides: A Comprehensive Guide to the Peloponnesian War. New York: Free Press, 1996.

Strategic Concept for the Defense and Security of the Members of the North Atlantic Treaty Organization. "The Alliance's Strategic Concept.” Adopted by Heads of State and Government at the meeting of North Atlantic Council in Washington, DC April 24, 1999.

Strategic Concept for the Defense and Security of the Members of the North Atlantic Treaty Organization. “Active Engagement, Modern Defense.” Adopted by Heads of State and Government at the NATO Summit in Lisbon November 19-20, 2010.

NSC 68, "United States Objectives and Programs for National Security," Foreign Relations of the United States (1950), in the University of Wisconsin Digital Library. Accessed March 17, 2015. http://digital.library.wisc.edu/1711.dl/FRUS.

The Wales Declaration on the Transatlantic Bond. Heads of State and Government participating in the meeting of the North Atlantic Council in Wales, September 5, 2014.

Thies, Wallace J. Why NATO Endures. New York: Cambridge University Press, 2009.

Walker, Martin. “Variable Geography: America’s Mental Maps of a Greater Europe.” International Affairs 76, no.3 (2000): 459-474.

Weinrod, W. Bruce. “The Future of NATO.” Mediterranean Quarterly 23, no.2 (Spring 2012): $1-14$. 